\title{
Snakes in a seasonally dry tropical forest in northeastern Brazil
}

\author{
Washington Luiz Silva Vieira $^{1 *}{ }^{\mathbb{D}}$, Jayene Aysla Mendonça Brito ${ }^{2}$, Erivágna Rodrigues de Morais $^{2}$, Daniel \\ Chaves Vieira ${ }^{2}$, Kleber Silva Vieira ${ }^{3}$ \& Eliza Maria Xavier Freire ${ }^{4}$ \\ ${ }^{1}$ Universidade Federal da Paraíba, Departamento de Sistemática e Ecologia, Laboratório de Ecofisiologia Animal, \\ CEP 58059-970, João Pessoa, PB, Brasil. \\ ${ }^{2}$ Universidade Federal da Paraíba, Centro de Ciências Agrárias, Programa de Pós-Graduação em Biodiversidade, \\ CEP 58397-000, Areia, PB, Brasil. \\ ${ }^{3}$ Universidade Estadual da Paraíba, Departamento de Ciências Biológicas e da Saúde, CEP 58109-753, \\ Campina Grande, PB, Brasil. \\ ${ }^{4}$ Universidade Federal do Rio Grande do Norte, Departamento de Botânica, Ecologia e Zoologia, CEP 59072-900, \\ Natal, RN, Brasil. \\ "Corresponding author: Washington L. S. Vieira, e-mail: wlsvieira@yahoo.com.br \\ VIEIRA, W.L.S., BRITO, J.A.M., MORAIS, E.R., VIEIRA, D.C., VIEIRA, K.S., FREIRE, E.M.X. Snakes \\ in a seasonally dry tropical forest in northeastern Brazil. Biota Neotropica 20(3): e20190850. https://doi. \\ org/10.1590/1676-0611-BN-2019-0850
}

\begin{abstract}
This study aimed to provide information on composition, abundance, and estimated snakes richness in an area of arboreal Caatinga (seasonally dry tropical forest) and analyze patterns of faunistic similarity between assemblages of snakes in the semiarid region of northeastern Brazil. The snakes found within the Fazenda Almas Natural Private Reserve (RPPN Fazenda Almas) were sampled during a 10-year period, with monthly monitoring, employing time constrained search, pitfall traps with drift fences, and donations from local collectors. Twenty-two snake species were recorded, with a predominance of terrestrial species with diurnal-nocturnal activity patterns. The species accumulation curves reached its asymptote, indicating that all possible species in the study area had been recorded. Our results indicated that the snake fauna in the study area is similar to other snake assemblages in localities with Caatinga vegetation in the Sertaneja Depression ("Depressão Sertaneja") drylands, and that those assemblages constitute faunistic units typical of the interior of northeastern Brazil.
\end{abstract}

Keywords: Biodiversity; faunistic, similarities; Serpentes; species, richness; semiarid, region.

\section{Serpentes em uma floresta tropical sazonalmente seca no nordeste do Brasil}

Resumo: Este estudo objetivou fornecer informações sobre composição, estimativa de riqueza de espécies e abundância de serpentes em uma área de Caatinga arbórea (floresta tropical sazonalmente seca) e analisar a ocorrência de padrões de similaridade faunística entre as assembleias de serpentes na região semiárida do nordeste do Brasil. A fauna de serpentes da Reserva Particular do Patrimônio Natural Fazenda Almas (RPPN Fazenda Almas) foi amostrada durante um período de dez anos de monitoramento mensal, usando busca visual limitada por tempo, armadilhas de queda com cercas direcionadoras e doações por coletores locais. Vinte e duas espécies foram registradas e houve predominância de serpentes terrestres e com padrões de atividade diurna-noturna. A curva de acumulação de espécies atingiu a assíntota indicando que foi possível registrar todas as espécies que ocorrem na área de estudo. Nossos resultados indicaram que a fauna de serpentes na área de estudo é semelhante a outras taxocenoses de serpentes em localidades com vegetação de Caatinga nas terras áridas das "Depressões Sertanejas", e que essas taxocenoses constituem unidades faunísticas típicas do interior do nordeste do Brasil. Palavras-chave: Biodiversidade; similaridade, faunística; Serpentes; riqueza de espécies; região, semiárida. 


\section{Introduction}

The Caatinga biome extends throughout interior of northeastern region of Brazil and the northern part of the state of Minas Gerais and covers an area of approximately 852,261 km² (Ab'Sáber 1977, Prado 2003, Silva et al. 2017). The predominant vegetation type is the seasonally dry tropical forest and woodlands (SDTFW) (Pennington et al. 2009, Queiroz et al. 2017). The SDTFW comprises at least thirteen different phytophysiognomies with elevated densities of woody plants, known collectively as caatingas, whose production of leaves and flowers are dependent on seasonal rainfall (Andrade-Lima 1981, Prado 2003).

The mean annual rainfall in the Caatinga biome varies between 200 and $700 \mathrm{~mm}$, with mean annual temperatures varying from $25^{\circ}$ to $27^{\circ}$ $\mathrm{C}$ (Pennington et al. 2009). An important characteristic of the Caatinga is its high interannual rainfall variability with severe droughts that can last up to two years (Nimer 1972). The strong seasonal dryness makes even the rainy period sub-humid, and the dry season, lasts from five to seven months, almost totally arid (Ab’Sáber 1977).

The Caatinga has traditionally been described as a biome with low species richness and low numbers of endemic species, with its snake fauna is composed of elements that occupy the diagonal of open South American vegetation formations (Vanzolini 1974, Vanzolini \& Williams 1981, Vanzolini 1988). However, the biome has been shown to be an important component of Brazilian biodiversity, with a significantly diversified fauna comprising endemic and threatened species (Rodrigues 2003, Leal et al. 2005, Albuquerque et al. 2012, Guedes et al. 2014a, Pereira-Filho et al. 2017).

Studies focusing on snake assemblages of northeastern Brazil have been quite limited and largely concentrated in coastal Atlantic Forest (e.g., Santana et al. 2008, França et al. 2012, Rodrigues et al. 2015, Sampaio et al. 2018). Although inventories of the reptiles (Squamata) in Brazilian semiarid regions have been undertaken in recent years (e.g., Garda et al. 2013, Cavalcanti et al. 2014, Dal Vechio et al. 2016, Caldas et al. 2016, Costa et al. 2018), information concerning Caatinga snakes are generally limited to preliminary taxonomic lists derived from short term inventories. There have been few studies presenting detailed data concerning the natural history of the species found there (Vitt \& Vangilder 1983, Mesquita et al. 2013a).

Species richness is an essential measure to evaluate local and regional diversities. Studies of faunistic composition contribute greatly to our understanding on biodiversity and are, consequently, important components of ecological models and conservation strategies (Gotelli $\&$ Colwell 2001). Within that context, regional faunistic inventories are indispensable for providing a better comprehension of the structure, functioning, and natural variability of natural communities, and constitute an essential tool for conservation decision-making (Quintela et al. 2006). As such, the present study was designed to provide information concerning the composition, estimated species richness, and abundance of snakes in an area of Caatinga SDTFW, and to analyze the occurrence of faunistic similarity patterns between snake assemblages in the semiarid region of northeastern Brazil.

\section{Materials and Methods}

\section{Study area}

The present study was conducted in the Fazenda Almas Private Natural Reserve (RPPN Fazenda Almas), which covers a total of 5,500 hectares, of which 3,505 hectares (63.7\%) correspond to protected area (Figure 1).

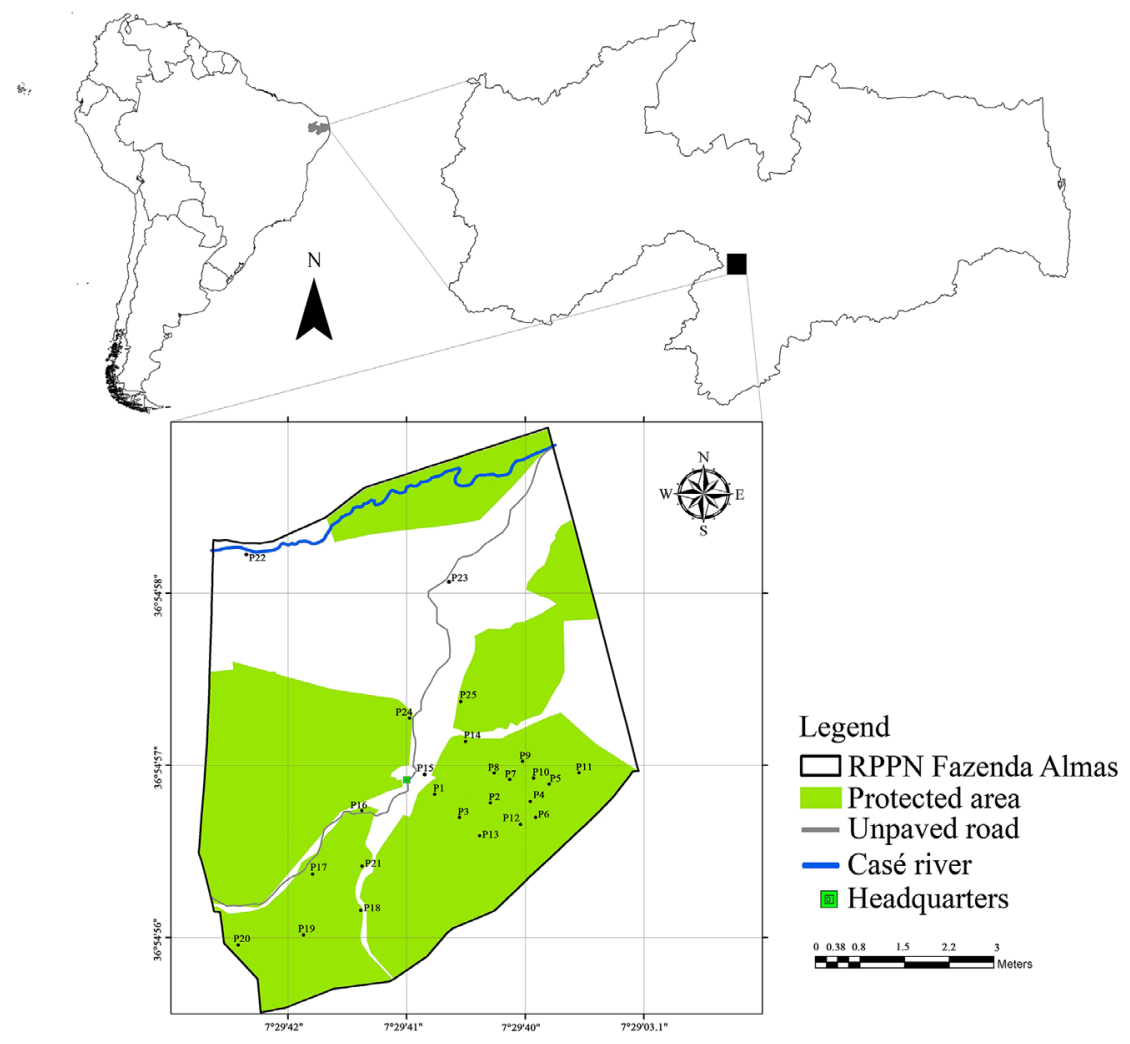

Figure 1. Schematic map showing the study site location and sampled points in the State of Paraíba, Brazil. Points 1-6 refer to pitfall traps lines, while points 7-25 were sampled by time constrained search. 
The RPPN Fazenda Almas is located in the Cariri western region, municipality of São José dos Cordeiros, state of Paraíba, northeastern Brazil (7²8'15"S; 36 52'51' W, 500-800 m above sea level). The RPPN Fazenda Almas comprises an area of arboreal Caatinga vegetation (seasonally dry tropical forest) in an excellent state of conservation. The phytophysiognomies of that vegetation varying from dense arboreal to arboreal-shrub forms, intermixed with rock outcrops (rupicolous habitats) with hyperxerophilic vegetation (Figure 2) (Lima \& Barbosa 2014).
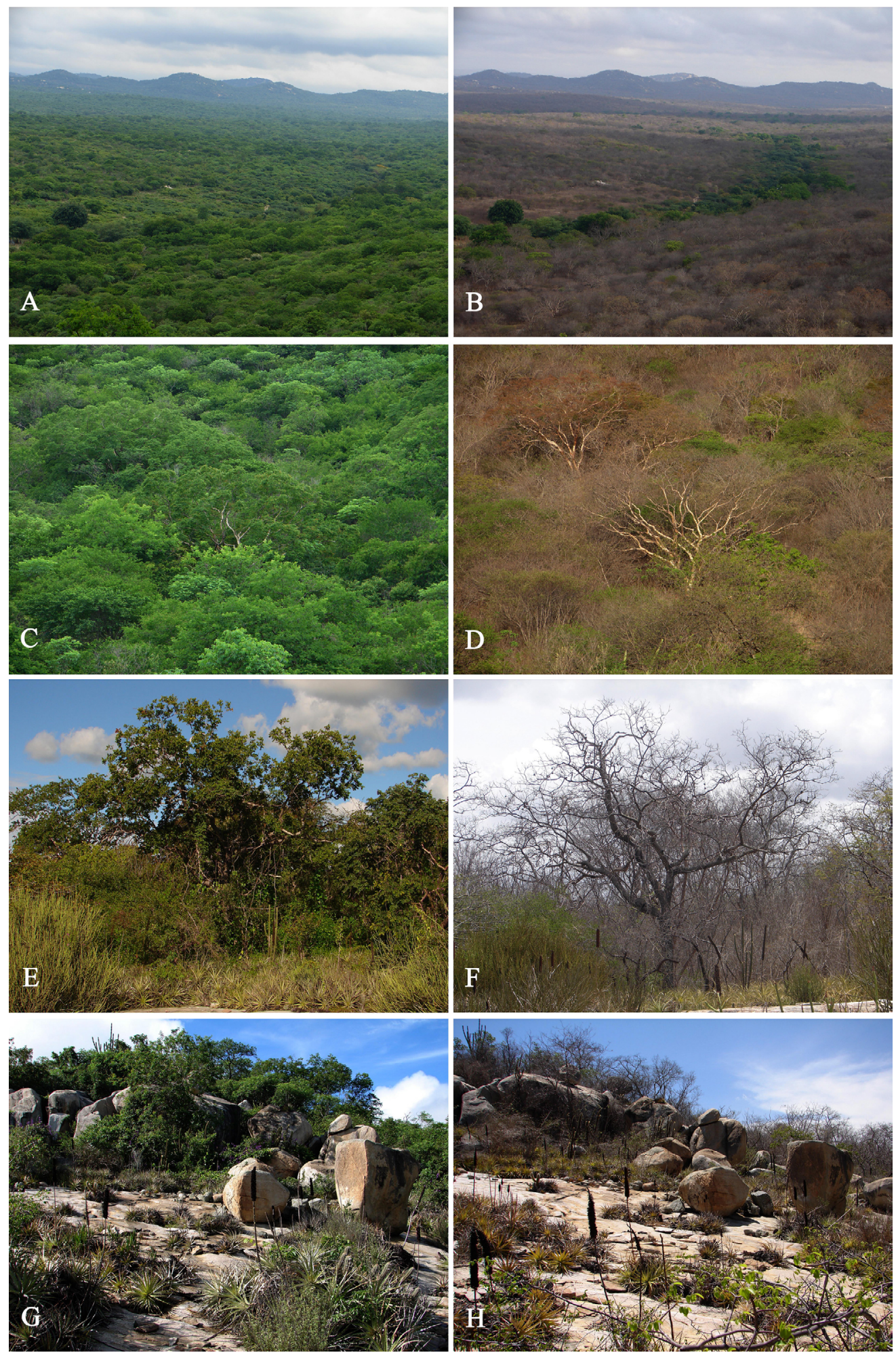

Figure 2. Phytophysiognomies of Caatinga seasonally dry tropical forests at RPPN Fazenda Almas, municipality of São José dos Cordeiros, state of Paraíba, northeastern Brazil. General aspect of the Caatinga vegetation (A. rainy season, B. dry season), dense arboreal Caatinga (C. rainy season, D. dry season), arborealshrub Caatinga (E. rainy season, F. dry season), and hyperxerophilic vegetation in rupicolous habitats on granitic-gneiss rock outcrops (G. rainy season, H. dry season). Photograph credits: Washington L.S Vieira. 
The average annual precipitation, temperature, and humidity are 560 $\mathrm{mm}( \pm 230 \mathrm{~mm}), 25^{\circ} \mathrm{C}$, and $65 \%$ respectively (Paraíba 1985). Rainfall is concentrated from February to May (Paraíba 1985, CPTEC 2018).

\section{Fieldwork/Snake Sampling}

Snakes were sampled during monthly excursions (each one of eight consecutive days, followed by 20-day intervals) from Jan/2008 to Dec/2018 (totaling 132 months of monitoring). Snake sampling was carried out using combinations of three sampling methods: timeconstrained search, pitfall traps with drift fences, and donations from local collectors (sensu Sawaya et al. 2008, Martins \& Nogueira 2012, Guyer \& Donnelly 2012). Geographical coordinates of the sampled points (time constrained search and pitfall traps with drift fences lines) are in Table 1.

Time constrained search were performed by two experienced researchers walking slowly, searching for snakes in all visual accessible microhabitats for at least 15 hours per day (daytime corresponded to $10 \mathrm{~h}$ from 06:00 to 12:00 and from 13:00 to 18:00, and night time corresponded to 5 hours, from 18:30 to 00:00). The sampling effort and encounter rate of snakes were based on person-hours of search (Martins \& Oliveira 1998, Guyer \& Donnelly 2012). The total sample effort was 240 person-hours per month.
The pitfall traps with drift fences (Corn 1994, Cechin \& Martins 2000) were placed along six lines containing ten 601 buckets each (totaling 60 buckets) that were buried to ground level, approximately $10 \mathrm{~m}$ apart, and interconnected by $1 \mathrm{~m}$ high plastic tarps (Figure 3 ). A minimum distance of $200 \mathrm{~m}$ was maintained between trap lines to reduce the possibility of dependent sampling. The buckets remained open for eight consecutive days per month but were covered during the 20-day intervals between excursions. The total sample effort was 11520 bucket-hours per month.

Local collectors represented a complementary method of sampling. Snakes were captured by local residents, reserve employees, other searchers, or encountered dead along access roads leading to RPPN Fazenda Almas (Sawaya et al. 2008, Martins \& Nogueira 2012). Local collectors were never encouraged to kill snakes, but they usually kill the snakes they encounter so we simply asked them to donated the snakes they killed and recorded some basic information about the location and time. The captured snakes were euthanized with an intracoelomic lidocaine injection $(0.25 \mathrm{ml}$ of a $100 \mathrm{mg} / \mathrm{ml}$ solution $)$, preserved in $10 \%$ formalin, and stored in 70\% ethanol (see Foster 2012), according to Portaria CFBio 148/2012-Anexo IV. The specimens were collected under an ICMBio collecting permit (SISBIO licenses 14105 and 65948-1).

Table 1. Sampled points used in the snake inventory in the RPPN Fazenda Almas, municipality of São José dos Cordeiros, state of Paraíba, northeastern Brazil. Points P1-P6 refer to pitfall traps lines, while points P7-P25 were sampled by time-constrained search. Geographical coordinates in degrees, minutes and seconds, based on the WGS84 datum.

\begin{tabular}{|c|c|c|c|}
\hline Sample points & Geographical coordinates & Elevation & Physiognomy \\
\hline $\mathrm{P} 1$ & $7^{\circ} 28^{\prime} 21^{\prime \prime} \mathrm{S} ; 36^{\circ} 53^{\prime} 40^{\prime \prime} \mathrm{W}$ & $616 \mathrm{~m}$ & Dense arboreal Caatinga \\
\hline $\mathrm{P} 2$ & $7^{\circ} 28^{\prime} 29^{\prime \prime} \mathrm{S} ; 36^{\circ} 53^{\prime} 22^{\prime \prime} \mathrm{W}$ & $718 \mathrm{~m}$ & Aboreal-shrub Caatinga \\
\hline P4 & $7^{\circ} 28^{\prime} 28^{\prime \prime} \mathrm{S} ; 36^{\circ} 53^{\prime} 14^{\prime \prime} \mathrm{W}$ & $708 \mathrm{~m}$ & Arboreal-shrub Caatinga \\
\hline P5 & $7^{\circ} 28^{\prime} 22^{\prime \prime} \mathrm{S} ; 36^{\circ} 53^{\prime} 08^{\prime \prime} \mathrm{W}$ & $693 \mathrm{~m}$ & Dense arboreal Caatinga \\
\hline P8 & $7^{\circ} 28^{\prime} 21^{\prime \prime S} ; 36^{\circ} 53^{\prime} 22^{\prime \prime} \mathrm{W}$ & $693 \mathrm{~m}$ & Dense arboreal Caatinga \\
\hline P9 & $7^{\circ} 28^{\prime} 17^{\prime \prime S} ; 36^{\circ} 53^{\prime} 14^{\prime \prime} \mathrm{W}$ & $681 \mathrm{~m}$ & Dense arboreal Caatinga \\
\hline $\mathrm{P} 10$ & $7^{\circ} 28^{\prime} 22^{\prime \prime S} ; 36^{\circ} 53^{\prime} 10^{\prime \prime} \mathrm{W}$ & $687 \mathrm{~m}$ & Rock outcrops \\
\hline P11 & $7^{\circ} 28^{\prime} 20^{\prime \prime} \mathrm{S} ; 36^{\circ} 53^{\prime} 0.4^{\prime \prime} \mathrm{W}$ & $659 \mathrm{~m}$ & Dense arboreal Caatinga \\
\hline $\mathrm{P} 15$ & $7^{\circ} 28^{\prime} 13^{\prime \prime S} ; 36^{\circ} 53^{\prime} 49^{\prime \prime} \mathrm{W}$ & $603 \mathrm{~m}$ & Arboreal-shrub Caatinga \\
\hline P16 & $7^{\circ} 28^{\prime} 32^{\prime \prime S} ; 36^{\circ} 54^{\prime} 20^{\prime \prime} \mathrm{W}$ & $674 \mathrm{~m}$ & Arboreal-shrub Caatinga \\
\hline $\mathrm{P} 17$ & $7^{\circ} 29^{\prime} 6 " \mathrm{~S} ; 36^{\circ} 54^{\prime} 43^{\prime \prime} \mathrm{W}$ & $714 \mathrm{~m}$ & Rock outcrops \\
\hline P18 & $7^{\circ} 30^{\prime} 9^{\prime \prime S} ; 36^{\circ} 54^{\prime} 0.6^{\prime \prime} \mathrm{W}$ & $637 \mathrm{~m}$ & Arboreal-shrub Caatinga \\
\hline P19 & $7^{\circ} 30^{\prime} 18^{\prime \prime} \mathrm{S} ; 36^{\circ} 54^{\prime} 35^{\prime \prime} \mathrm{W}$ & $702 \mathrm{~m}$ & Arboreal-shrub Caatinga \\
\hline $\mathrm{P} 20$ & $7^{\circ} 30^{\prime} 24^{\prime \prime S} ; 36^{\circ} 55^{\prime} 9^{\prime \prime} \mathrm{W}$ & $684 \mathrm{~m}$ & Arboreal-shrub Caatinga \\
\hline $\mathrm{P} 21$ & $7^{\circ} 29^{\prime} 4^{\prime \prime S} ; 36^{\circ} 54^{\prime} 17^{\prime \prime} \mathrm{W}$ & $632 \mathrm{~m}$ & Dense arboreal Caatinga \\
\hline $\mathrm{P} 22$ & $7^{\circ} 26^{\prime} 6^{\prime \prime} \mathrm{S} ; 36^{\circ} 55^{\prime} 12^{\prime \prime} \mathrm{W}$ & $581 \mathrm{~m}$ & Arboreal-shrub Caatinga \\
\hline $\mathrm{P} 23$ & $7^{\circ} 26^{\prime} 9^{\prime \prime S} ; 36^{\circ} 53^{\prime} 26^{\prime \prime} \mathrm{W}$ & $582 \mathrm{~m}$ & Arboreal-shrub Caatinga \\
\hline
\end{tabular}




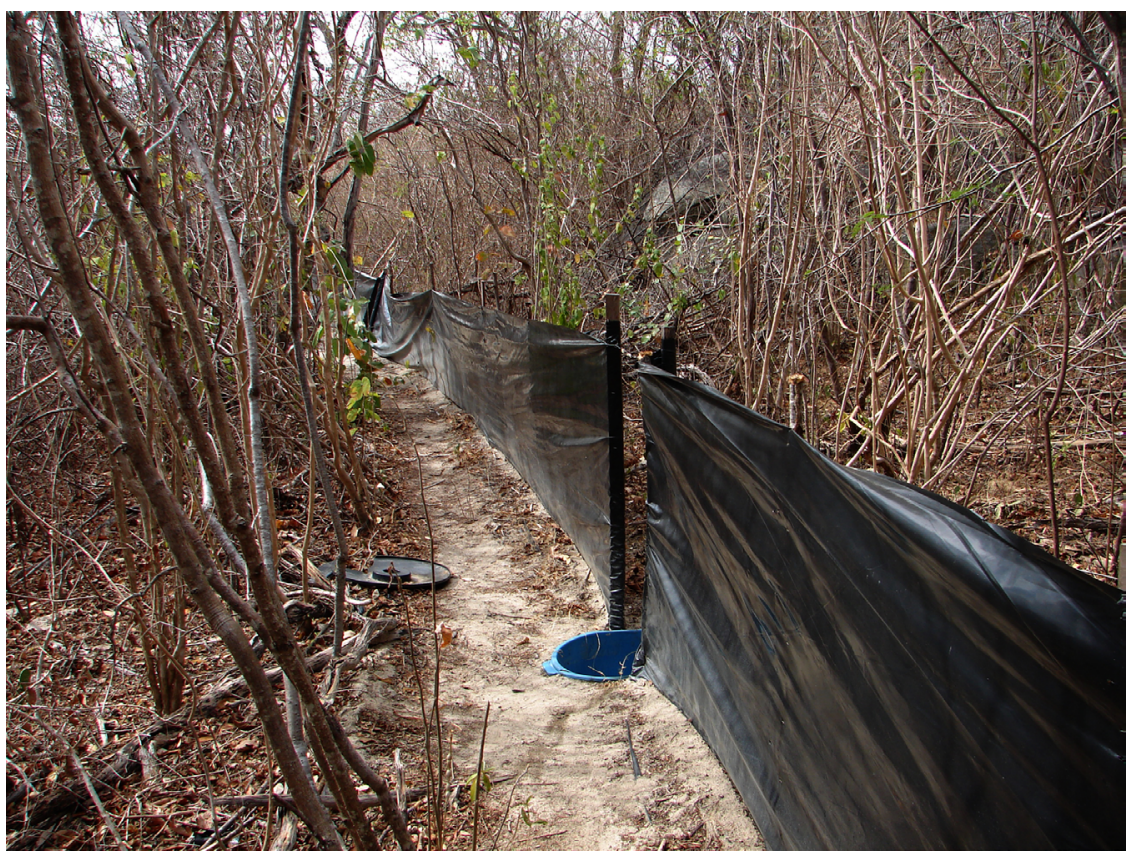

Figure 3. Pitfall trap with drift fences installed in arboreal-shrub Caatinga at the RPPN Fazenda Almas, municipality of São José dos Cordeiros, state of Paraíba, northeastern Brazil. Photograph credits: Washington L.S Vieira.

The specimens not collected were recorded, marked with cuts on their ventral scales, and subsequently liberated into their natural habitat. Voucher specimens were deposited in the herpetological collection of the Universidade Federal da Paraíba (CHUFPB; Appendix 1). The taxa nomenclature used in the present study followed Grazziotin et al. (2012) and Costa and Bérnils (2018).

\section{Data analyses}

To evaluate sampling efficiency, we constructed species accumulation curves for snakes sampled at the RPPN Fazenda Almas, constructed from 1000 randomizations without replacements, considering individual species abundance (Gotelli \& Colwell 2001, Magurran 2004, Colwell 2011). Additionally, we used species richness estimators based on abundance data (Chao 1 and ACE) and based on nonparametric incidence (Bootstrap, Chao 2, ICE, Jacknife 1 and 2) to determine the expected richness of snakes in the area (Colwell \& Coddington 1994, Magurran 2004, Colwell 2011). Species accumulation curves and richness estimates were constructed in EstimateS 9.1.0 software (Colwell 2011).

Faunistic similarity analysis was designed to compare the species composition at the RPPN Fazenda Almas with snake assemblages from other phytophysiognomies in localities of SDTFW of the Caatinga Ecoregions in northeastern Brazil (sensu Veloso et al. 2002, Silva et al. 2017) (Figure 4), as follows (alphabetically ordered by ecoregion and Brazilian state): Complexo Chapada Diamantina Ecoregion (CCD): Bahia: Chapada Diamantina National Park, Palmeiras municipality (Magalhães et al. 2015). Complexo Ibiapaba - Araripe Ecoregion (CI-A): Ceará: Chapada do Araripe (Ribeiro et al. 2012); Piauí: Barras municipality (Benício et al. 2015a); Castelo do Piauí municipality (Rodrigues \& Prudente 2011). Depressão Sertaneja Meridional Ecoregion (DSM): Bahia: Fazenda Caraíbas, Mucugê municipality (Freitas et al. 2012); Juazeiro municipality (Freitas et al. 2016); Pernambuco: Exu municipality (Vanzolini et. al. 1980, Vitt \&
Vangilder 1983); Fazenda Saco, Serra Talhada municipality (Miranda \& Santos 2011); Floresta Nacional de Negreiros (Pereira et al. 2015); Parque Nacional do Catimbau (Muniz \& Santos 2011, Pedrosa et al. 2014). Depressão Sertaneja Setentrional Ecoregion (DSS): Ceará: Estação Ecológica de Aiuaba (Costa et al. 2018); Fazenda Vale do Curu, Pentecoste municipality (Mesquita et al. 2013a); Paraíba: Fazenda Tanque da Onça, Imaculada municipality (Pereira-Filho et al. 2017); Estação Experimental de São João do Cariri (Freire et. al. 2009, PereiraFilho et al. 2017); Rio Grande do Norte: Chapada do Apodi (Lima-Verde 1976); ESEC Seridó, Serra Negra do Norte municipality (Freire et. al. 2009, Caldas et al. 2016). Dunas do São Francisco Ecoregion (DSF): Bahia: Xique-Xique municipality (Rodrigues 1996, Rodrigues \& Juncá 2002). Raso da Catarina Ecoregion (RC): Bahia: Estação Ecológica Raso da Catarina (Garda et al. 2013). São Francisco-Gurguéia Ecoregion (SF-G): Piauí: Fazenda Paquetá, municipality of Batalha (Silva et al. 2015); Parque Nacional da Serra da Capivara (Cavalcante et al. 2014); Parque Nacional da Serra das Confusões (Dal Vechio et al. 2016); Picos municipality (Benício et al. 2015b); Maranhão: Fazenda Varjota, municipality of Timon (Silva et al. 2016). Only snakes identified to the species level and for which no doubts existed concerning their correct identification were used in the analyses of faunistic similarity.

The faunistic similarity in species composition between RPPN Fazenda Almas and other localities in Caatinga was investigated using the Jaccard coefficient, UPGMA as a clustering algorithm, and an ordination technique, the Nonmetric Multidimensional Scaling method (NMDS), with qualitative data and the Jaccard index as a similarity measure (Clarke \& Warnick 1994, Bastazini et al. 2007, Legendre \& Legendre 2012, Xavier et al 2015). A stress value was used as a representative measure of the groupings, and values $<0.20$ were considered acceptable (Clarke \& Warnick 1994, Legendre \& Legendre 2012). Multivariate analyses were performed using R 3.5.0 software (R Development Core Team 2018), utilizing the vegan 2.5-2 package (Oksanen et al. 2018). 


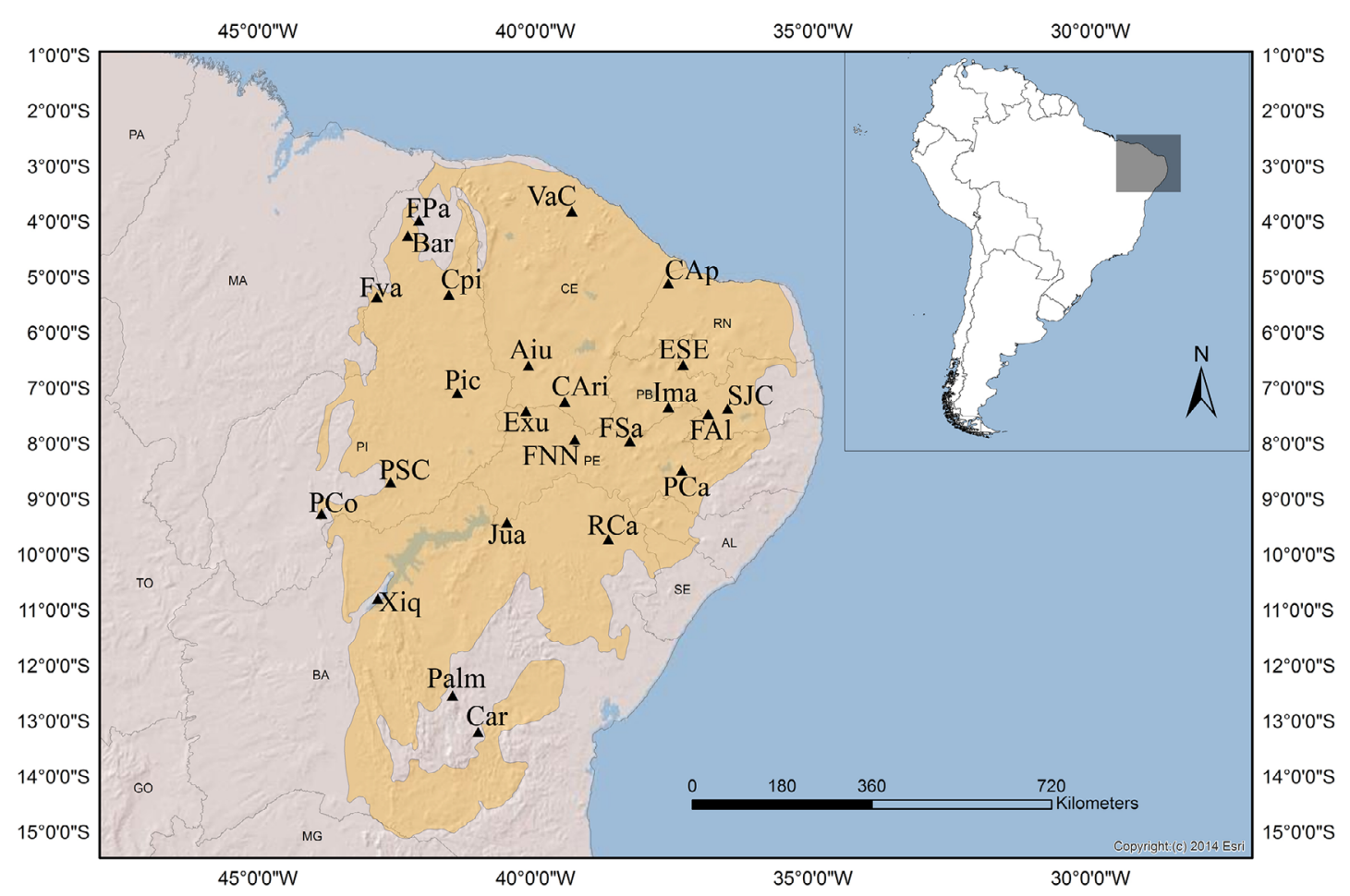

Figure 4. Geographic location of RPPN Fazenda Almas (FAl), municipality of São José dos Cordeiros, state of Paraíba, northeastern Brazil, and other areas used in the analyses of faunistic similarity of snake assemblages in Caatinga seasonally dry tropical forests, northeastern Brazil. Brazilian State acronyms: BA, Bahia; CE, Ceará; MA, Maranhão; PB, Paraíba; PE, Pernambuco; PI, Piauí; RN, Rio Grande do Norte. Abbreviations of locality names: Car: Caraíbas-BA, Palm: Palmeiras-BA, RCa: Estação Ecológca Raso da Catarina-BA, Cap: Chapada do Apodi-RN, Vac: Fazenda Vale do Curu-CE, FAl: RPPN Fazenda Almas-PB, SJC: Estação Experimental de São João do Cariri-PB, ESE: Estação Ecológica Seridó-RN, Aiu: Estação Ecológica de Aiuaba-CE, FSa: Fazenda Saco-PE, FNN: Floresta Nacional de Negreiros-PE, Ima: Imaculada-PB, Pic: Picos-PI, Jua: Juazeiro-BA, Exu: Exu-PE, CAri: Chapada do Araripe-CE, PCa: Parque Nacional do Catimbau-PE, Xiq: Xique-Xique-BA, FVa: Fazenda Varjota -MA, FPa: Fazenda Paquetá-PI, Cpi: Castelo do Piauí-PI, PCo: Parque Nacional da Serra das Confusões-PI, PSC: Parque Nacional da Serra da Capivara-PI, Bar: Barras-PI, DSS: Depressão Sertaneja Setentrional, DSM: Depressão Sertaneja Meridional, DSF: Dunas do São Francisco, RC: Raso da Catarina, CCD: Complexo da Chapada Diamantina, CI-A: Complexo Ibiapaba-Araripe, SF-G: São Francisco-Gurguéia.

Information concerning habits, activity periods and continental distributions of the species recorded at the RPPN Fazenda Almas (see Table 2) was obtained from the literature (see Duellman 1978, Dixon \& Soini 1986, Zimmerman \& Rodrigues 1990, Cadle \& Greene 1993, Argôlo 2004, Martins \& Oliviera 1998, Giraudo 2004, Marques \& Sazima 2004, Santos et al. 2005, Zanella \& Cechin 2006, Santana et al. 2008, França et al. 2008, Pereira-Filho et al. 2017, Guedes et al. 2018, Sampaio et al. 2018).

\section{Results}

The snake assemblage at the RPPN Fazenda Almas comprised 22 species belonging to 18 genera and 6 families: Dipsadidae, with 13 species (59.1\%), Boidae 3 species (13.6\%), Colubridae 2 species, Viperidae 2 species (9.1\% each), Leptotyphlopidae 1 species (4.5\%), and Elapidae 1 species (4.5\%) (Table 2 and Figure 5). None of those species appeared on the lists of animals threatened with extinction (Portaria $n^{\circ} 444 / 2014$ ) prepared by the ICMBio/MMA(2018) or the IUCN (2019). Only three of those species are endemic to the Caatinga biome, according to Rodrigues (2003), Guedes et al. (2014a), and Pereira-Filho et al. (2017) (Table 2).
In relation to their habits and activity periods, nine species were terrestrial $(40.9 \%)$, six semi-arboreal $(27.3 \%)$, four arboreal $(18.2 \%)$, two fossorial (9.1\%), and one cryptozoic (4.6\%) (Table 2). Of all of those, nine were active in both periods (nocturnal - diurnal) $(40.9 \%)$, seven exclusively nocturnal (31.8\%) and six diurnal (27.3\%) (Table 2).

The combination of all sampling methods recorded 22 species and resulted in the capture of 448 individuals (Table 2), from which, 150 were marked and released for eventual posterior recapture. Nevertheless, no recaptures were recorded in this study. Considering a combination of all sampling methods, the most abundant species were Bothrops erythromelas (Amaral, 1923) $(\mathrm{n}=58,13.0 \%)$, Thamnodynastes phoenix Franco, Trevine, Montingelli \& Zaher, $2017(\mathrm{n}=52,11.6 \%)$, Oxyrhopus trigeminus Duméril, Bibron \& Duméril, $1854(\mathrm{n}=50$, $11.2 \%)$, Leptodeira annulata (Linnaeus, 1758) $(\mathrm{n}=42,9.4 \%)$, and Erythrolamprus viridis (Günther, 1862) $(\mathrm{n}=31,6.3 \%)$ (Table 2). The use of time constrained search allowed the recording of 22 species and 211 individuals (Table 2). The species with the largest number of recorded individuals using that sampling method were Oxyrhopus trigeminus $(\mathrm{n}=32)$ and Bothrops erythromelas $(\mathrm{n}=26)$. Philodryas olfersii (Lichtenstein, 1823) was only recorded using the visual search (Table 2). 
Table 2. List of snake species recorded at the RPPN Fazenda Almas, São José dos Cordeiros municipality, state of Paraíba, northeastern Brazil. Physiognomies (PY): DAC-dense arboreal Caatinga, ASC-arboreal-shrub Caatinga, RO-rock outcrops, Habits: F-fossorial, T-terrestrial, AB-arboreal, SAB-semi-arboreal, C-cryptozoic, Activity: D-diurnal, N-nocturnal, ND-nocturnal-diurnal. Sampling methods: TCS-time constrained search, PTDF-pitfall traps with drift fences, LC-local collectors. $\mathrm{N}$-number of individuals observed, RA\%-relative abundance. Continental distribution in biomes: CE-Cerrado neotropical savannah, CA-Caatinga seasonally dry tropical forest, FA-Atlantic Forest, AM-Amazonia, CH-Chaco, PP-Pampas (South American lowlands), PA-Pantanal.

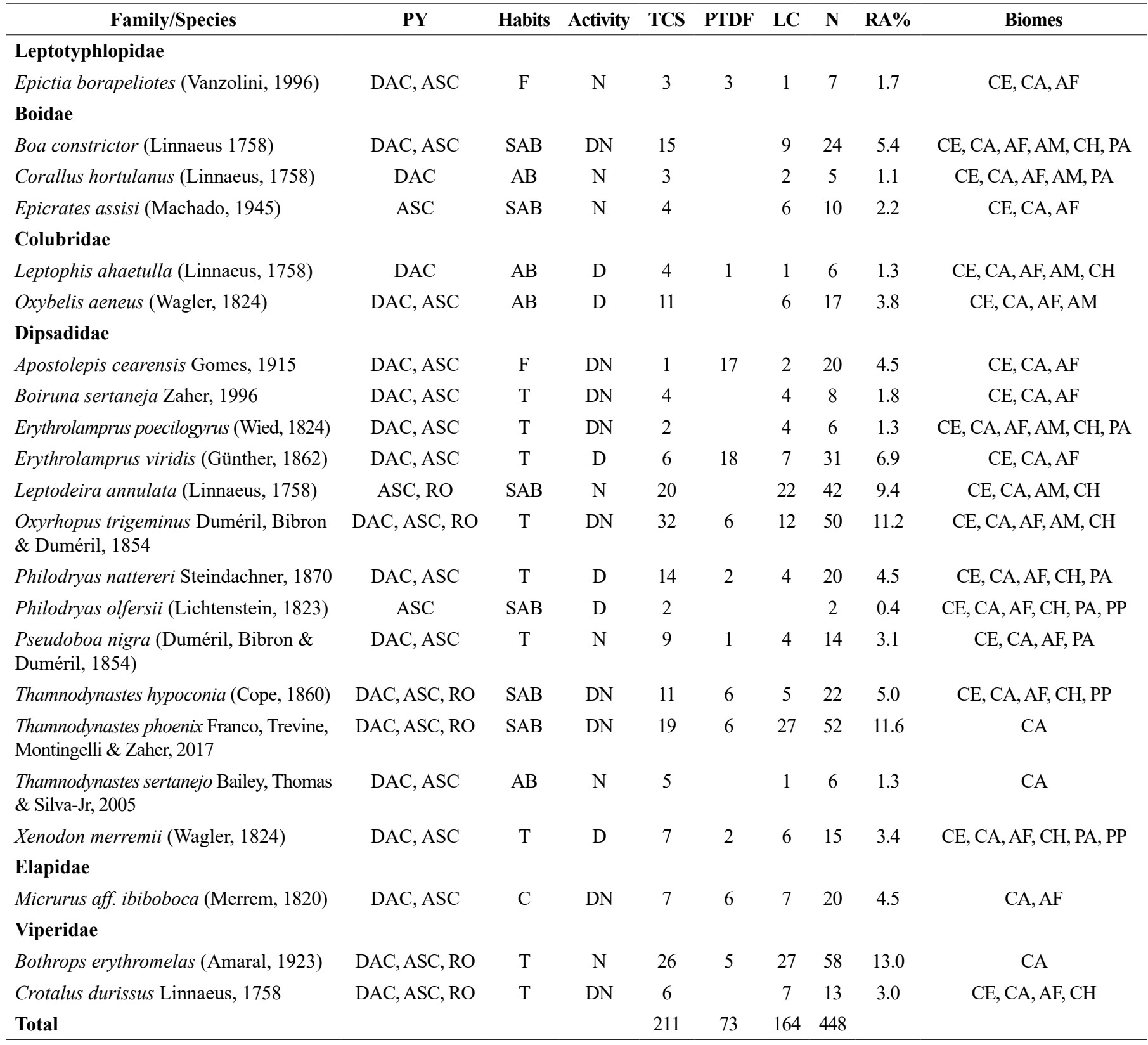

The use of pitfall traps with drift fences recorded 12 species and 73 individuals (Table 2), with no species recorded exclusively by that sampling method. That method recorded the largest numbers of individuals of Apostolepis cearensis Gomes, $1915(\mathrm{n}=17)$ and Erythrolamprus viridis ( $\mathrm{n}$ $=18$ ) (Table 2). Local collectors recorded 21 species and 164 individuals, although no species was recorded solely by that method (Table 2). The species with the largest numbers of records made by local collectors were B. erythromelas $(\mathrm{n}=27)$ and Thamnodynastes phoenix $(\mathrm{n}=27)$.

The species accumulation curves (constructed using the combined results of all three sampling methods) reached its asymptote at approximately 280 recorded individuals (Figure 6A), corresponding to the 75th sampling month. Time constrained search reached its asymptote at approximately 141 recorded individuals (Figure 6B), corresponding to the 80th sampling month. The species accumulation curves for pitfall traps and local collectors demonstrate a tendency to stabilize (Figure 6C and D). All richness estimators indicated the existence of 22 species, except for Jacknife 2, which estimated a lower richness than the total number of species actually encountered (Table 3 ). At the end of the study period, one doubleton (Philodryas olfersii) and no singletons were recorded at RPPN Fazenda Almas. 

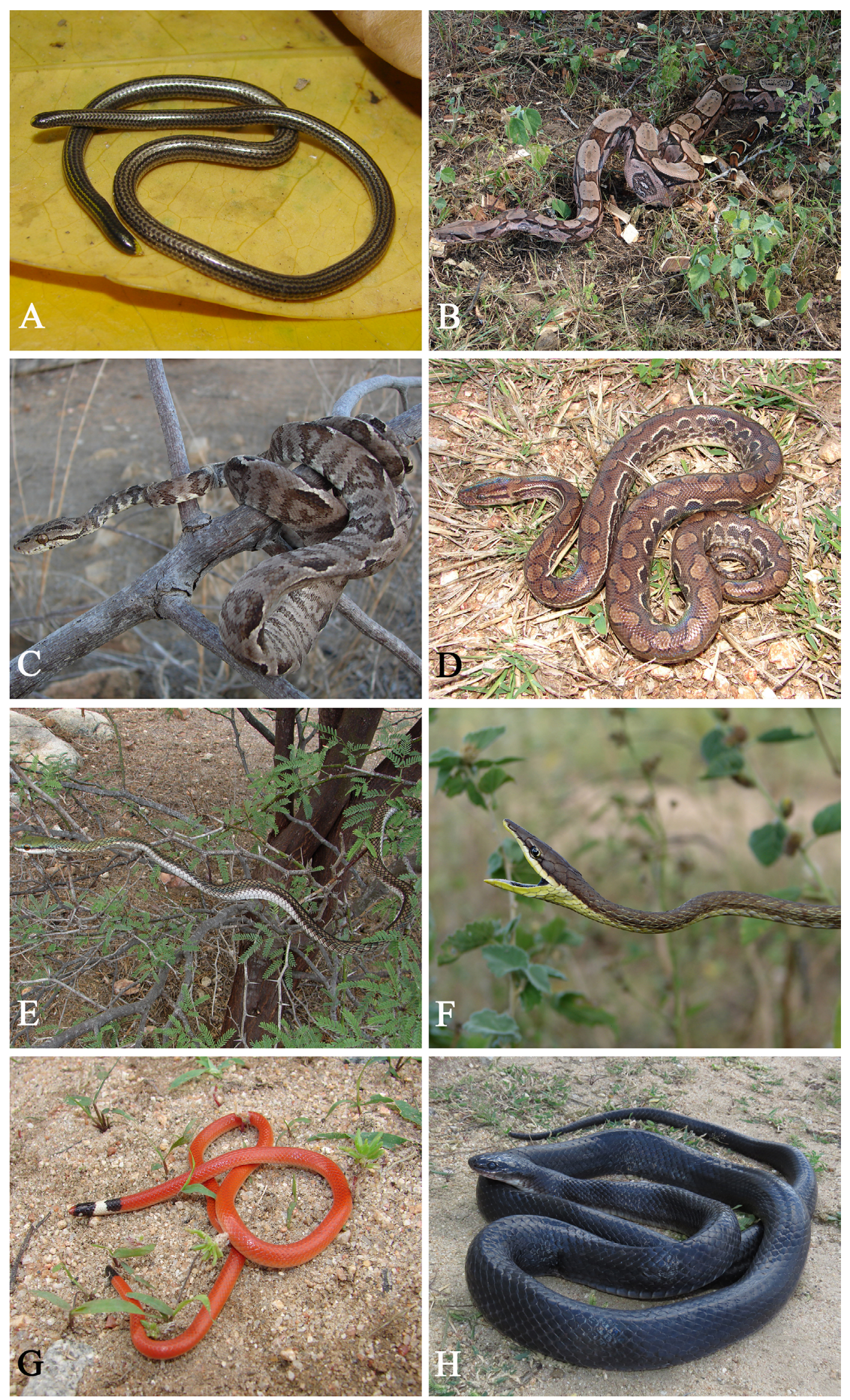

continue figure $5 .$. 

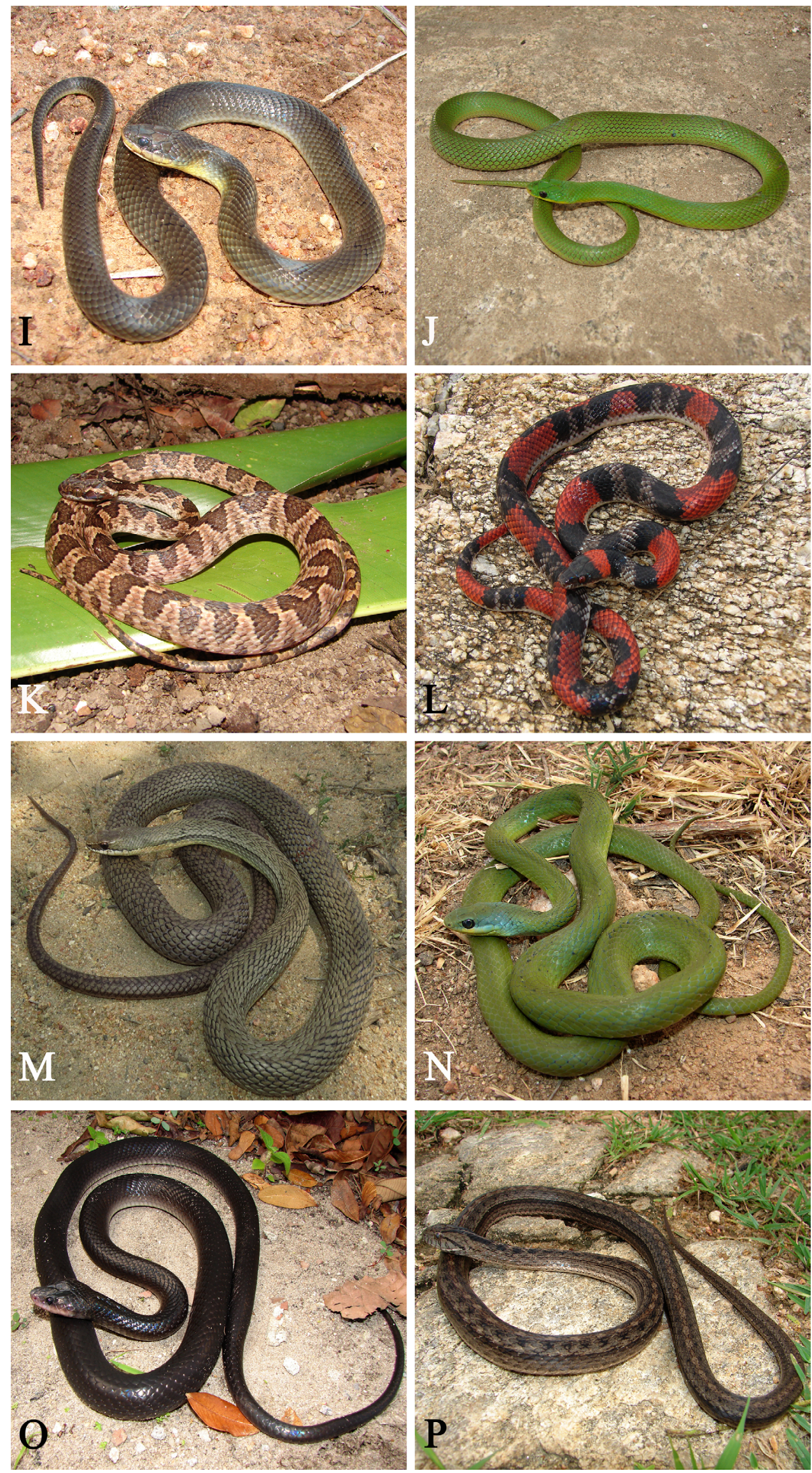

continue figure $5 \ldots$ 
Vieira, WLS. et al.
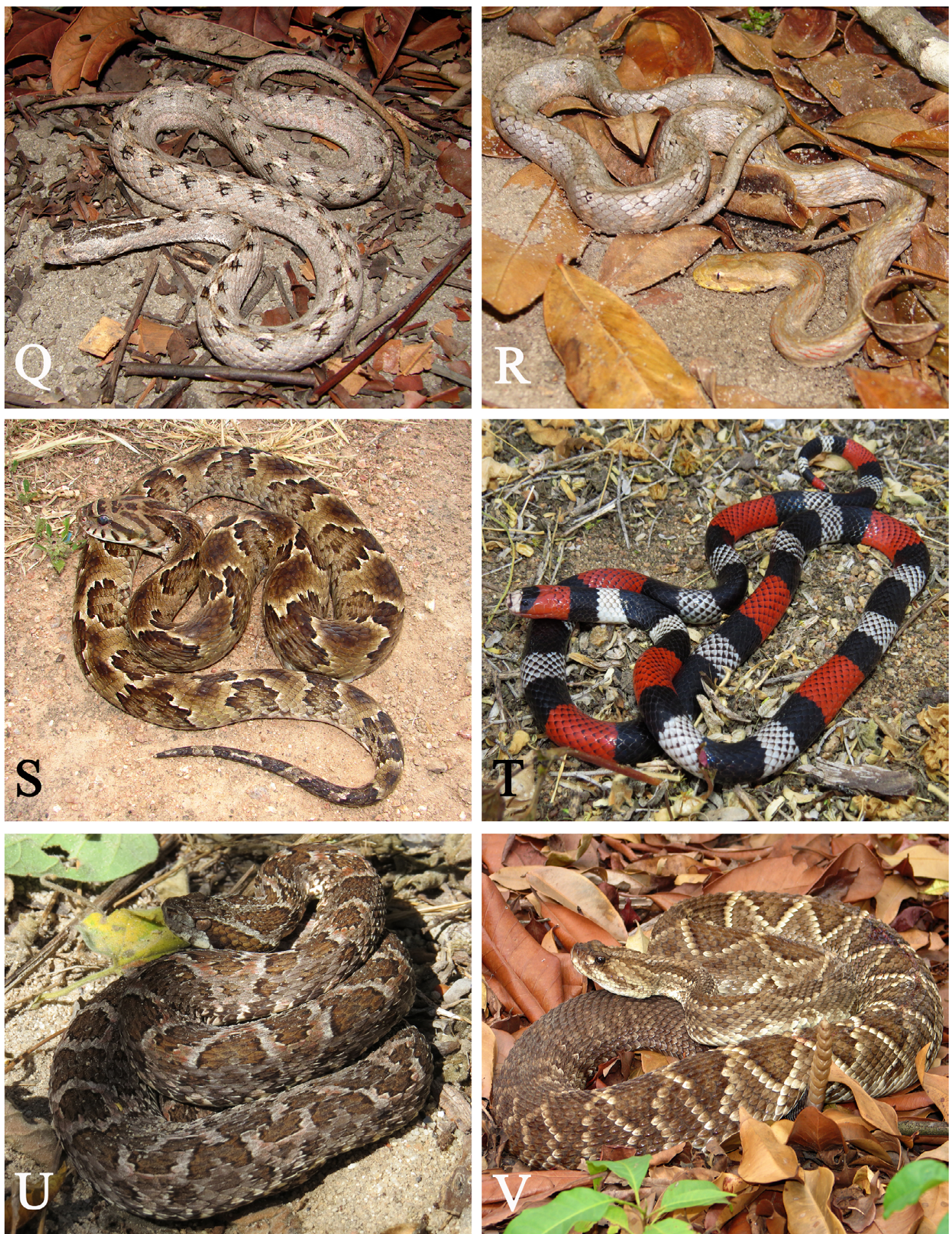

Figure 5. Snakes recorded in the RPPN Fazenda Almas, Paraíba State, municipality of São José dos Cordeiros, state of Paraíba, northeastern Brazil. Leptotyphlopidae: A - Epictia borapeliotes, Boidae: B - Boa constrictor, C - Corallus hortulanus, D Epicrates assisi, Colubridae: E - Leptophis ahaetulla, F - Oxybelis aeneus, Dipsadidae: G - Apostolepis cearensis, H - Boiruna sertaneja, I - Erythrolamprus poecilogyrus, J - Erythrolamprus viridis, K - Leptodeira annulata, L - Oxyrhopus trigeminus, M - Philodryas nattereri, N - Philodryas olfersii, O - Pseudoboa nigra, P - Thamnodynastes hypoconia, Q - Thamnodynastes phoenix, R - Thamnodynastes sertanejo, S - Xenodon merremii, Elapidae: T - Micrurus aff. ibiboboca, Viperidae: U - Bothrops erythromelas, V - Crotalus durissus. Photograph credits: Washington L.S Vieira. 

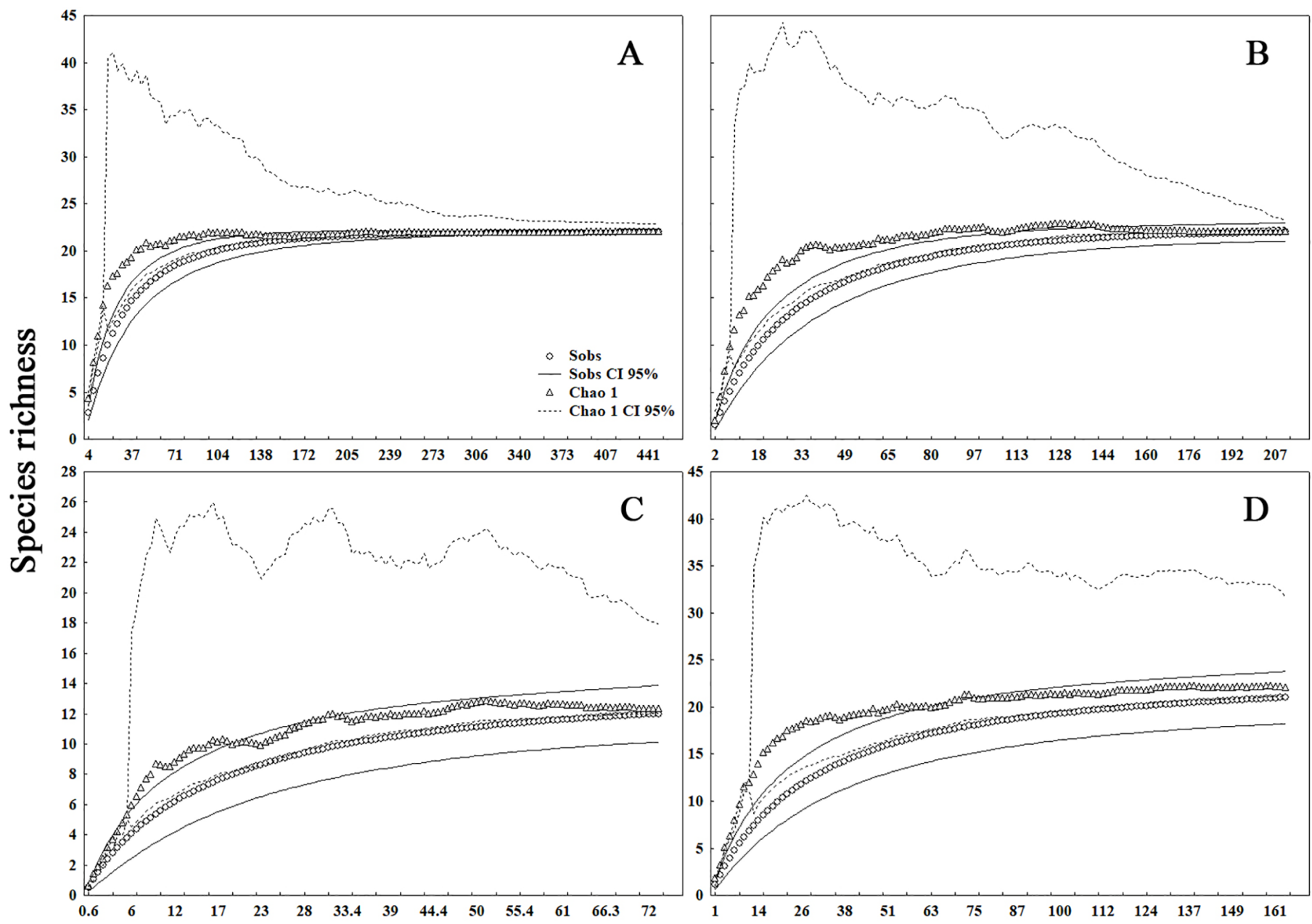

\section{Number of individuals}

Figure 6. Accumulation curves for snakes sampled at the RPPN Fazenda Almas, municipality of São José dos Cordeiros, state of Paraíba, northeastern Brazil, constructed from 1000 randomizations without replacements, considering individual species abundance.. A - combination of all sampling methods, B - time constrained search, C - pitfall traps with drift fences, D - local collectors. Sobs $=$ total number of species observed in a sample, $\mathrm{CI}=95 \%$ confidence interval.

Table 3. Species richness estimates for snake assemblage at RPPN Fazenda Almas, São José dos Cordeiros municipality, state of Paraíba, northeastern Brazil, using different estimators based on the numbers of individuals recorded. CSM-combination of all sampling methods, TCS-Time constrained search, PTDF-pitfall traps with drift fences, LC-local collectors. Sobs $=$ total number of species observed in a sample, $\mathrm{CI}=95 \%$ confidence interval. The Jacknife 1 and 2 , Bootstrap, ACE, and ICE estimators did not generate confidence intervals.

\begin{tabular}{|c|c|c|c|c|}
\hline & \multicolumn{4}{|c|}{ Sampling Methods } \\
\hline & CSM & TCS & PTDF & $\mathbf{L C}$ \\
\hline Estimators & $\begin{array}{c}\text { Mean }( \pm \mathrm{SD}) / 95 \% \\
\text { CI (Lower and } \\
\text { UpperBound) }\end{array}$ & $\begin{array}{c}\text { Mean }( \pm \text { SD) } / 95 \% \\
\text { CI (Lower and } \\
\text { UpperBound) }\end{array}$ & $\begin{array}{c}\text { Mean }( \pm \text { SD) } / 95 \% \\
\text { CI (Lower and } \\
\text { UpperBound) }\end{array}$ & $\begin{array}{c}\text { Mean }( \pm \text { SD) } / 95 \% \\
\text { CI (Lower and } \\
\text { UpperBound) }\end{array}$ \\
\hline Observed richness (sobs) & $22.00(0.00) / 22.00-22.00$ & $22.00(0.50) / 10.03-22.97$ & $12.00(0.96) / 10.12-13.88$ & $21.00(1.42) / 18.22-23.78$ \\
\hline Chao 1 & $22.00(0.36) / 22.00-22.87$ & $22.00(0.17) / 22.50-23.17$ & $12.33(0.92) / 12.02-17.90$ & $21.99(1.81) / 21.09-31.63$ \\
\hline Jacknife 1 & $22.00(0.0)$ & $22.99(0.99)$ & $13.98(1.40)$ & $23.98(1.70)$ \\
\hline Jacknife 2 & $21.02(0.0)$ & $22.02(0.0)$ & $14.00(0.0)$ & $24.97(0.0)$ \\
\hline Bootstrap & $22.15(0.0)$ & $22.80(0.0)$ & $13.07(0.0)$ & $22.53(0.0)$ \\
\hline $\mathrm{ACE}$ & $22.00(0.0)$ & $22.28(0.0)$ & $12.82(0.0)$ & $22.07(0.0)$ \\
\hline
\end{tabular}


Cluster analysis and NMDS demonstrated the same similarity patterns regarding the different snake assemblages (Figures 7 and 8, respectively). Cluster analysis (cophenetic correlation coefficient $=0.86$ ) based on 70 species and 23 Caatinga localities generated two groups: a smaller group formed by three snake assemblages in different Caatinga Ecoregions, and a larger second group composed of the remaining assemblages (Figure 7). The larger second group also comprised two faunistic sets: a smaller set composed of snake assemblages from the São Francisco-Gurguéia and Complexo Ibiapaba-Araripe ecoregions, and another set composed of a group of snake assemblages from those same two ecoregions and of faunas from the Dunas do São Francisco and the Depressions Sertaneja Setentrional and Meridional (Figure 7).

Non-metric multidimensional scaling $(\mathrm{NMDS}$, stress $=0.01)$ indicated greater similarities between the Setentrional and Meridional Dryland Depressions than between other Caatinga ecoregions (Figure 8). The snake fauna at RPPN Fazenda Almas demonstrated greater similarity with the faunas of Fazenda Vale do Curu and Chapada do Apodi (see Lima-Verde 1976, Mesquita et al. 2013a), all localities in the Depressão Sertaneja Setentrional ecoregion (Figure 8).

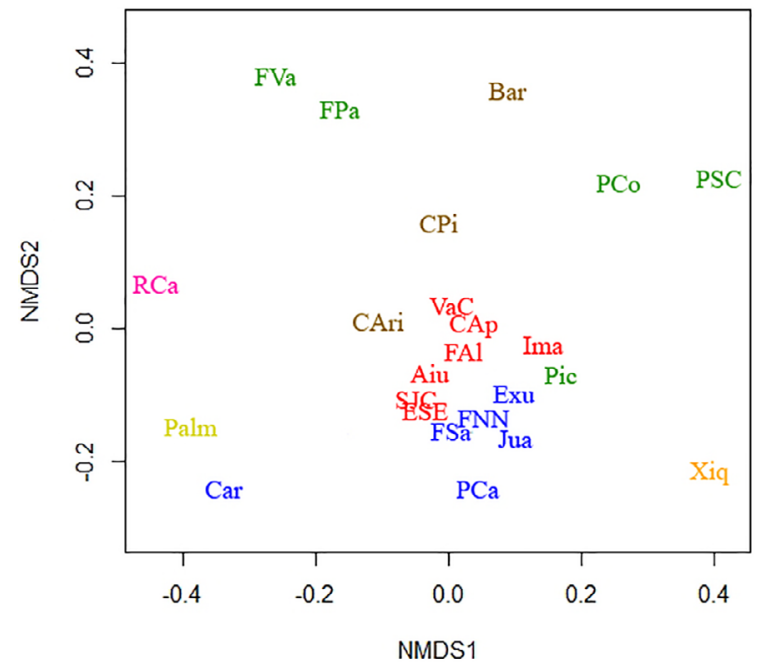

Figure 8. Non-metric multidimensional scaling (NMDS, stress 0.01 ) ordination of snakes assemblages in 24 localities in Caatinga ecoregions in northeastern Brazil. Complexo da Chapada Diamantina (yellow), Complexo IbiapabaAraripe (brown), Depressão Sertaneja Meridional (blue), Depressão Sertaneja Setentrional (red), Dunas do São Francisco (orange), Raso da Catarina (pink), São Francisco-Gurguéia (green). Abbreviations in Figure 4.

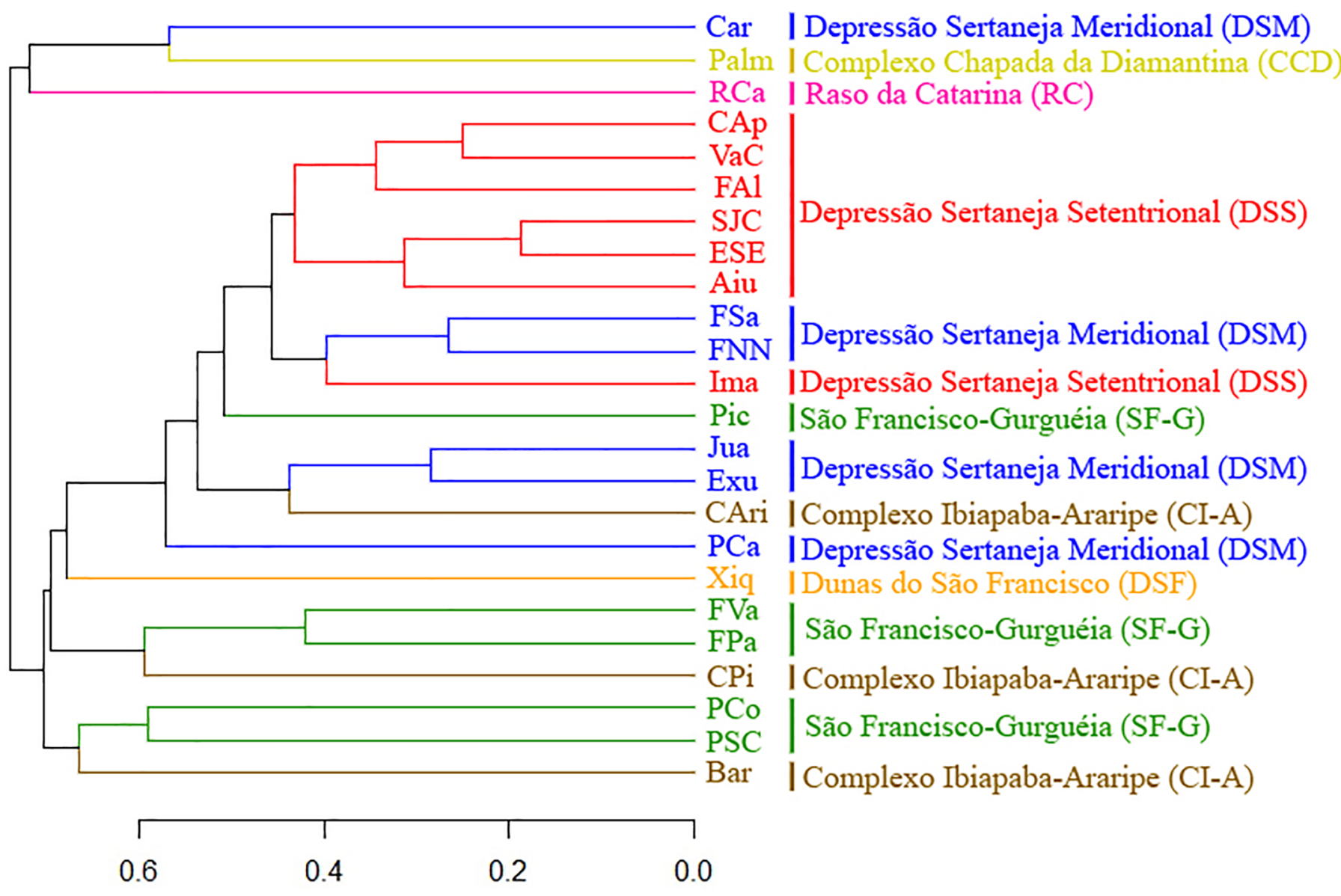

Figure 7. Dendrogram of cluster analysis (UPGMA, cophenetic correlation coefficient $=0.86$ ) based on snake species compositions in 24 localities in Caatinga seasonally dry tropical forest ecoregions, northeastern Brazil. Abbreviations in Figure 4. 


\section{Discussion}

The snakes at RPPN Fazenda Almas were largely terrestrial and semi-arboreal, with wide distributions throughout the Caatinga biome as well as other Brazilian biomes. The predominance of xenodontines and species with wide geographic distributions in the study area makes it similar to other neotropical snake assemblages (e.g., Vitt \& Vangilder 1983, Strüssman \& Sazima 1993, Rodrigues 1996, , Sawaya et al. 2008, Mesquita et.al. 2013a, Pedrosa et al. 2014, Rodrigues et al. 2015, PereiraFilho et al. 2017, Sampaio et.al 2018) and follows a pattern of snake composition described for the Caatinga biome, including endemic species, such as Bothrops erythromelas, Thamnodynastes sertanejo, and T. phoenix (Guedes et al. 2014a, 2014b). In relation to the activity periods of those snakes at RPPN Fazenda Almas, greater numbers of diurnal-nocturnal and exclusively nocturnal species were recorded, being different from a study undertaken by Vitt \& Vangilder (1983) and Mesquita et al. (2013a) who reported a dominance of strictly diurnal species in the Caatinga biome. The absence of aquatic/semi-aquatic species in the study area was probably related to the existence of only temporary bodies of water there (such as small streams, lakes, pools, and artificial waterholes) with very short periods of water retention and long periods without any standing water. Those temporary aquatic habitats do not favor the occurrence of snakes that are dependent on permanent bodies of water, and explains why aquatic/semi-aquatic species represent only a small component of the snake fauna of the Caatinga biome (Guedes et al. 2014a).

The snake assemblage at RPPN Fazenda Almas was rich in species as compared to other localities in the Caatinga biome (e.g., Miranda \& Santos 2011, Muniz \& Santos 2011, Garda et al. 2013, Cavalcante et al. 2014, Pedrosa et al. 2014, Benício et al. 2015a and b, Pereira et al. 2015, Silva et al. 2015, Pereira-Filho et al. 2017, Costa et al. 2018). The high species richness recorded at RPPN Fazenda Almas may reflect the long-duration study period (10 years of monthly monitoring) and the fact that the area represents the most well-preserved remnant of Caatinga vegetation in the state of Paraíba (see Lima \& Barbosa 2014). Species records in faunistic studies can be influenced by the sampling efforts employed (duration of the study), the size of the area, as well as habitat heterogeneity and structure (Strüssman \& Sazima 1993, Ugland 2003, Mesquita et.al. 2013b, Rodrigues et al. 2015). Conserved environments are generally more heterogeneous and structured, providing adequate habitats for wide varieties of species as compared to homogeneous (and consequently less structured) environments (Lieberman 1986, Viana et al. 2001, Pardini \& Umetsu 2006, Macedo et al. 2008).

Snake abundance in the study area is similar to that found in other Caatinga localities, with a dominance of the species Bothrops erythromelas, Thamnodynastes phoenix, Oxyrhopus trigeminus, and Erythrolamprus viridis. Those species are generalists and demonstrate significant plasticity in terms of their diets and habitat uses (Vanzolini et al. 1980, Vitt \& Vangilder 1983). They occur in forested and shrub environments, as well as in perianthropic areas (Pereira-Filho et al. 2017) and are widely distributed throughout the Caatinga biome (Guedes et al. 2014a). Unfortunately, most studies of the snake fauna of the Caatinga have been short-term inventories that produced only preliminary species lists (Guedes et al. 2014a). Very few publications contain abundance data (e.g., Borges-Nojosa \& Arzabe 2005, Borges-Nojosa \& Santos 2005, Borges-Nojosa \& Cascon 2005, Freire et. al. 2009, Garda et al. 2013, Cavalcante et al. 2014, Dal Vechio et al. 2016) and even then, usually significantly underestimate true snake abundances, which prevents any secure comparisons between different Caatinga sites.
Time-constrained search and the use of local collectors are efficient methods for determining the richness and abundance of species in a given area, as opposed to pitfall traps with drift fences. Although snakes are often rather difficult to encounter (as compared to lizards and anurans) as many species demonstrate cryptic or secretive behaviors (Sazima \& Haddad 1992, Sawaya et al. 2008), time-constrained search and local collectors have proven to be adequate methods for sampling snakes in many other herpetofaunistic inventories undertaken in the Caatinga and other Brazilian biomes (e.g., Sazima \& Haddad 1992, Sawaya et al. 2008, Santana et al. 2008, Freire et al. 2009, Pontes et al. 2008, Mesquita et al. 2013b, Caldas et al. 2016, Pereira-Filho et al. 2017, Sampaio et al. 2018). While visual search represents a low-cost technique, their strength will depend on the sampling effort and experience of the researchers involved (Mesquita et al. 2013b). The same is true for the use of local collectors, who largely record only the most generalist species (in terms of habitat use), which have less propensity to flee (Sawaya 2003).

Pitfall traps with drift fences are widely used for sampling amphibians and reptiles (Corn 1994, Greenberg et al. 1994, Cechin \& Martins 2000, Fisher \& Rochester 2012), but were not found to be very efficient in the present study, recording only smaller numbers of species and individuals (with the exception of Apostolepis cearensis and Erythrolamprus viridis). Although the use of pitfalls traps is quite common, this method should only be considered as a complementary sampling technique associated with other sampling methods in long-duration studies of snake assemblages (Cunha \& Nascimento 1993, Greenberg et al. 1994, Cechin $\&$ Martins 2000). As such, comparing the deficiencies of each sampling method and considering financial and time investments in relation to the numbers of species and individuals recorded, the use of pitfall traps in short-term studies of snakes in Caatinga areas with shallow rocky soils is not indicated (Cechin \& Martins 2000, Mesquita et al. 2013b).

The combination of three sampling techniques and extended fieldwork efforts (10 years of monthly monitoring), the absence of singletons, and species accumulation curves reaching their asymptotes, made it possible to affirm that probably all of the snake species occurring in RPPN Fazenda Almas were recorded in the present study. The Jacknife 2 estimator predicted a richness less than the actual total number of species recorded. Such unusual result may indicate the inefficiency of that estimator for snake inventories in Caatinga sites. Sampling is considered complete in biodiversity studies when each species is represented by at least two individuals, without any singletons, as there will only be an extremely low probability of any additional species being recorded even with additional sampling efforts (Chao et al. 2009). The performances of the richness estimators here, the absence of singletons, and the shape of the species accumulation curves allowed a secure interpretation of each sampling method, and indicated the extremely reduced probability of encountering more species in the snake assemblage with greater additional sampling efforts (Colwell \& Coddington 1994, Chao et al. 2009).

The snake fauna in the study area demonstrated high similarity with typical assemblages found in Caatinga sites in crystalline terrains of the Sertaneja depressions. Localities with similar phytophysiognomies and at identical latitudes likewise demonstrated similarities in terms of their snake faunas. Faunistic similarities tend to appear as a function of geographic proximity between localities but decrease along latitudinal gradients (Nekola \& White 1999, Willig \& Bloch 2006). Stochastic processes and the evolutive and biogeographic histories of species lineages can also affect assemblage compositions (Cadle \& Greene 1993, Martins \& Oliveira 1998, Fraga et al. 2011). 
The Caatinga snakes demonstrate species distribution patterns that suggest the occurrence of regionalization of assemblages in diverse habitats throughout that biome (Guedes et al. 2014b). Similarities among the assemblages analyzed in the present study were noted between most of the areas in the Sertanejas Meridional and Sententrional depressions, which form a large group composed of localities whose snake fauna is composed of very common and widely distributed species in arid landscapes dominated by xeromorphic vegetations. This snake fauna can be considered typical of interplateau depressions, corroborating that lowland semiarid Caatinga regions constitute a faunistic unit characteristic of the interior of northeastern Brazil (Guedes et al. 2014b). A study employing parsimony analysis of endemism evidenced that dryland Sertaneja depressions have large similarities in terms of their lizard faunas, and those faunas are largely composed of widely distributed species plus relictual elements generally related to less arid climates along the edges of those ecoregions (Mesquita et al. 2017). As such, the areas included within Sertaneja depressions have very similar Squamata reptile faunas that constitute important components of the Caatinga biota, in spite of the fact that Meridional and Sententrional Sertaneja depression ecoregions demonstrate distinct climatic, geological, and physiognomic parameters (Velloso et al. 2002).

The RPPN Fazenda Almas demonstrates an elevated snake species richness and constitutes an important conservation area for snakes of the Caatinga, reflecting its very well-preserved Caatinga vegetation (Lima \& Barbosa 2014), in spite of the fact that is located in a region that has been greatly impacted by deforestation, mining, extensive cattle grazing, predatory hunting, and with susceptibility to desertification (Souza et al. 2004, Alves et al. 2012). It should be pointed out that RPPN Fazenda Almas is located in an area considered to have priority for conservation efforts and is of extreme biological importance to the semiarid region (sensu Veloso et al. 2002, MMA 2002, Tabarelli \& Silva 2003). In spite of the growing number of herpetofaunistic inventories in the Caatinga biome during the last 10 years (Guedes et al. 2014a, Mesquita et al. 2017), there is still a need for long term studies in all Caatinga ecoregions. Further studies would complement and/or corroborate the species distribution patterns already published for the different Caatinga ecoregions, and will increase our understanding on the ecology, species richness, and biogeography of snake assemblages in the Caatinga seasonally dry tropical forests.

\section{Supplementary Material}

The following online material is available for this article:

Appendix 1 - Voucher specimens of snakes collected at the RPPN Fazenda Almas, municipality of São José dos Cordeiros, state of Paraíba, northeastern Brazil.

\section{Acknowledgments}

The authors thank Sra. Eunice Braz (in memoriam) and the current administrator of RPPN Fazenda Almas, Arimatéia Braz, for allowing and supporting this study, Roberto Lima and Maria RV Barbosa for their support and collaboration, ICMBio for conceding the collecting permits (SISBIO licenses 14105 and 65948-1), the Conselho Nacional de Desenvolvimeto Científico e Tecnológico ( $\mathrm{CNPq}$ ), process 477121/2011-0 and 476058/2013-9, for financial support, and the anonymous reviewers for their contributions.

\section{Author Contributions}

Washington Luiz Silva Vieira: Substantial contribution in the concept and design of the study; Contribution to data collection; Contribution to data analysis and interpretation; Contribution to manuscript preparation and critical revision, adding intellectual content.

Jayene Aysla Mendonça Brito: Contribution to data analysis and interpretation; Contribution to manuscript preparation and critical revision, adding intellectual content.

Erivagana Rodrigues de Morais: Contribution to data analysis and interpretation; Contribution to manuscript preparation and critical revision, adding intellectual content.

Daniel Chaves Vieira: Contribution to data analysis and interpretation; Contribution to manuscript preparation and critical revision, adding intellectual content.

Kleber Silva Vieira: Contribution to data analysis and interpretation; Contribution to manuscript preparation and critical revision, adding intellectual content.

Eliza Maria Xavier Freire: Substantial contribution in the concept and design of the study; Contribution to data collection; Contribution to data analysis and interpretation; Contribution to manuscript preparation and critical revision, adding intellectual content

\section{Conflicts of Interest}

The authors declare that they have no conflict of interest related to the publication of this manuscript.

\section{References}

AB'SÁBER, N.S. 1977. Problemática da desertificação e da savanização no Brasil intertropical. Geomorfologia 53:1-19.

ALBUQUERQUE, U.P., LIMA-ARAÚJO, E., EL-DEIR, A.C.A., LIMA, A.L.A., SOUTO, A., BEZERRA, B.M., FERRAZ. E.M.N., FREIRE, E.M.X., SAMPAIO, E.V.S.B., LAS-CASAS, F.M.G., MOURA, G.J.B., PEREIRA, G.A., MELO, J.G., RAMOS, M.A., RODAL, M.J.N., SCHIEL, N., LYRA-NEVES, R.M., ALVES, R.R.N., AZEVEDO-JÚNIOR, S.M., TELINO-JÚNIOR, W.R. \& SEVERI, W. 2012. Caatinga revisited: ecology and conservation of an important seasonal dry forest. Sci. World. J.:2-19.

ALVES, R.R.N., PEREIRA-FILHO, G.A., VIEIRA, K.S., SOUTO, W.M.S., MENDONÇA, L.E.T., MONTENEGRO, P.F.G.P., ALMEIDA, W.O., VIEIRA, W.L.S. 2012. A zoological catalogue of hunted reptiles in the semiarid region of Brazil. J. Ethnobiol. Ethnomed. 8:1-29.

ANDRADE-LIMA, D. 1981. The caatinga dominium. Rev. Bras. Bot. 4:149-153.

ARGÔLO, A.J.S. 2004. As serpentes dos cacauais do sudeste da Bahia. Editus, Editora da UESC, Ilhéus.

BASTAZINI, C.V., MUNDURUCA, J.F.V., ROCHA, P.L.B. \& NAPOLI, M.F. 2007. Which environmental variables better explain changes in anuran community composition? A case study in the Restinga of Mata de São João, Bahia, Brazil. Herpetologica 63(4):459-471.

BENÍCIO, R.A., MESQUITA, P.C.M.D., CAVALCANTE, V.H.G.L. \& FONSECA, M.G. 2015a. Répteis de uma região de ecótono no estado do Piauí, nordeste do Brasil. Gaia Scientia 9(1):95-100.

BENÍCIO, R.A., LIMA, D.C. \& FONSECA, M.G. 2015b. Species richness of reptiles in a caatinga area in northeastern Brazil. Gaia Scientia 9(1):89-94.

BORGES-NOJOSA, D.M. \& ARZABE, C. 2005. Diversidade de anfíbios e répteis em áreas prioritárias para a conservação da Caatinga. In Análise da Biodiversidade do Bioma Caatinga (F.S. ARAÚJO, M.J.N. RODAL \& M.R.V. BARBOSA, eds.). Ministério do Meio Ambiente, Brasília, p.277-241.

BORGES-NOJOSA, D.M. \& CASCON, P. 2005. Herpetofauna da área da Reserva da Serra das Almas, Ceará. In Análise da Biodiversidade do Bioma Caatinga (F.S. ARAÚJO, M.J.N. RODAL \& M.R.V. BARBOSA, eds.). Ministério do Meio Ambiente, Brasília, p.245-260. 
BORGES-NOJOSA, D.M. \& SANTOS, E.M. 2005. Herpetofauna da área de Betânea e Floresta, Pernambuco. In Análise da Biodiversidade do Bioma Caatinga (F.S. ARAÚJO, M.J.N. RODAL \& M.R.V. BARBOSA, eds.). Ministério do Meio Ambiente, Brasília, p.277-291.

CADLE, J.E. \& GREENE, H.W. 1993. Phylogenetic patterns, biogeography, and the ecological structure of Neotropical snake assemblages. In Historical and Geographical Determinants of Community Diversity (R.E. RICKLEF\& D. SCHLUTER, eds.). University of Chicago Press, Chicago, p.281-293.

CALDAS, F.L.S., COSTA, T.B., LARANJEIRAS, D.O., MESQUITA, D.O. \& GARDA,A.A. 2016. Herpetofauna of protected areas in the Caatinga V: Seridó Ecological Station (Rio Grande do Norte, Brazil). Check List 12(4):1-14.

CAVALCANTI, L.B.Q., COSTA, T.B., COLLI, G.R., COSTA, G.C., FRANÇA, F.G.R., MESQUITA, D.O., PALMEIRA, C.N.S., PELEGRIN, N., SOARES, A.A.H.B., TUCKER, D.B. \& GARDA, A.A. 2014. Herpetofauna of protected areas in the Caatinga II: Serra da Capivara National Park, Piauí, Brazil. Check List 10(1):18-27.

CECHIN, S.Z. \& MARTINS, M. 2000. Eficiência de armadilhas de queda (pitfall traps) em amostragens de anfíbios e répteis no Brasil. Rev. Bras. Zool. 17(3):729-740.

CHAO, A., COLWELL, R.K., LIN, C. \& GOTELLI, N.J. 2009. Sufficient sampling for asymptotic minimum species richness estimators. Ecology 90(4):1125-1133.

CLARKE, K.R. \& WARWICK, R.M. 1994. Changes in Marine Communities: An Approach to Statistical Analyses and Interpretation. Natural Environment Research Council, Plymouth.

COLWELL, R.K. \& CODDINGTON, J. 1994. Estimating terrestrial biodiversity through estrapolation. Philos. Trans. R. Soc. Lond. Series B 345:101-118.

COLWELL, R.K. 2011. EstimateS: Statistical Estimation of Species Richness and Shared Species from Samples. Version 9.1.0. User's Guide and application published at: http://purl.oclc.org/estimates (last access on 30/11/2018).

CORN, P.S. 1994. Straight-line drift fences and pitfall traps. In Measuring and monitoring biological diversity: standard methods for amphibians (W.R HEYER, M.A. DONNELLY, R.W. MCDIARMID, L.C. HAYEK \& M.S. FOSTER, eds). Smithsonian Institution Press, Washington and London, p.109-117.

COSTA, H.C. \& BÉRNILS, R.S. 2018. Répteis do Brasil e suas Unidades Federativas: Lista de espécies. Herpetol. Braz. 89(1):11-57.

COSTA, T.B., LARANJEIRAS, D.O., CALDAS, F.L.S., SANTANA, D.O., SILVA, C.F., ALCÂNTARA, E.P., BRITO, S.V., GALDINO, J.Y., MESQUITA, D.O., FARIA, R.G., FRANÇA, F.G.R., ÁVILA, R.W. \& GARDA, A.A. 2018. Herpetofauna of protected areas in the Caatinga VII: Aiuaba Ecological Station (Ceará, Brazil). Herpetol. Notes 11:929-941.

CPTEC (CENTRO DE PREVISÃO DE TEMPO E ESTUDOS CLIMÁTICOS). 2018. Available at: http://www.cptec.inpe.br/proclima (last access on 15/12/2018).

CUNHA, O.R. \& NASCIMENTO, F.P. 1993. Ofídeos da Amazônia. As cobras da região do leste do Pará. Bol. Mus. Para. Emílio Goeldi. sér. Zoologia 9:1-191.

DAL VECHIO, F., TEIXEIRA JR, M., RECODER, R.S., RODRIGUES, M.T. \& ZAHER, H. 2016. The herpetofauna of Parque Nacional da Serra das Confusões, state of Piauí, Brazil, with a regional species list from an ecotonal area of Cerrado and Caatinga. Biota Neotrop. 16(3): e20150105. http:// dx.doi.org/10.1590/1676-0611-BN-2015-0105 (last access on 05/11/2017)

DIXON, J.R. \& SOINI, P. 1986. The Reptiles of the Upper Amazon Basin, Iquitos Region, Peru. Milwaukee Public Museum, Milwaukee, Wisconsin.

DUELLMAN, W.E. 1978. The biology of an equatorial herpetofauna in Amazonian Ecuador. Univ. Kans. Mus. Nat. Hist. Misc. Publ. 65:1-352.

FISHER, R.N. \& ROCHESTER, C.J. 2012. Pitfall-trap surveys. In Reptile Biodiversity Standard Methods for Inventory and Monitoring (W. Roy, MS McDiarmid, CGJ Foster, G Whitfield \& N. Chernoff, eds.). University of California Press, Berkeley, p.234-249.

FOSTER, M.S. 2012. Preparing reptiles as voucher specimens. In Reptile Biodiversity Standard Methods for Inventory and Monitoring (W. Roy, M.S. McDiarmid, C.G.J. Foster, G. Whitfield \& N. Chernoff, eds.). University of California Press, Berkeley, p.95-125.

FRAGA, R., LIMA, A.P. \& MAGNUSSON, W.E. 2011. Mesoscale spatial ecology of a tropical snake assemblage: the width of riparian corridors in central Amazonia. Herpetol. J. 21:51-57.
FRANÇA, F.G.R., MESQUITA, D.O., NOGUEIRA, C.C. \& ARAÚJO, A.F.B. 2008. Phylogeny and Ecology Determine Morphological Structure in a Snake Assemblage in the Central Brazilian Cerrado. Copeia 1:20-36.

FRANÇA, R.C., GERMANO, C.E.S. \& FRANÇA, F.G.R. 2012. Composition of a snake assemblage inhabiting an urbanized area in the Atlantic Forest of Paraíba State, Northeast Brazil. Biota Neotrop. 12(3):183-195. http:// dx.doi.org/10.1590/S1676-06032012000300019 (last access on 08/09/2013).

FREIRE, E.M.X., SUGLIANO, G.O.S., KOLODIUK, M.F., RIBEIRO, L.B., MAGGI, B.S., RODRIGUES, L.S., VIEIRA, W.L.S. \& FALCÃO, A.C.G.P. 2009. Répteis Squamata das caatingas do Seridó do Rio Grande do Norte e do Cariri Paraíba: síntese do conhecimento atual e perspectivas. In Recursos naturais das caatingas: uma visão multidisciplinar (E.M.X. Freire, ed.). Editora da Universidade Federal do Rio Grande do Norte, Natal, p.51-84.

FREITAS, M.A., VERÍSSIMO, D. \& UHLIG, V. 2012. Squamate Reptiles of the central Chapada Diamantina, with a focus on the municipality of Mucugê, state of Bahia, Brazil. Check List 8(1):16-22.

FREITAS, M.A., ENTIAUSPE-NETO, O.M., LIMA, T.O., NETO, J.S.S., ARAÚJO, D. \& SILVA, J.M.S. 2016. Bol. Mus. Biol. Mello Leitão 38(4):331-345.

GARDA, A.A., COSTA, T.B., SANTOS-SILVA, C.R., MESQUITA, D.O., FARIA, R.G., CONCEIÇÃO, B.M., SILVA, I.R.S., FERREIRA, A.S., ROCHA, S.M., PALMEIRA, C.N.S., RODRIGUES, R., FERRARI, S.F. \& TORQUATO, S. 2013. Herpetofauna of protected areas in the Caatinga I: Raso da Catarina Ecological Station (Bahia, Brazil). Check List 9(2):405-414.

GIRAUDO, A. 2004. Serpientes de la selva paranaense y del chaco húmedo. L.O.LA., Buenos Aires.

GOTELLI, N.J. \& COLWELL, R.K. 2001. Quantifying biodiversity: procedures and pitfalls in the measurement and comparison of species richness. Ecol. Lett. 4:379-391.

GRAZZIOTIN, F.G., ZAHER, H., MURPHY, R.W., SCROCCHI, G., BENAVIDES, M.A., ZHANG, Y.P. \& BONATTO, S.L. 2012. Molecular phylogeny of the new world Dipsadidae (Serpentes: Colubroidea): a reappraisal. Cladistics: 28:437-459.

GREENBERG, C.H., NEARY, D.G. \& HARRIS, L.D. 1994. A comparison of herpetofaunal sampling effectiveness of pitfall, single-ended, and doubleended funnel traps used with drift fences. J. Herpetol. 28:319-324.

GUEDES, T.B., NOGUEIRA, C. \& MARQUES, O.A.V. 2014a. Diversity, natural history, and geographic distribution of snakes in the Caatinga, Northeastern Brazil. Zootaxa 3863 (1):1-93.

GUEDES, T.B., SAWAYA, R.J. \& NOGUEIRA, C. 2014b. Biogeography, vicariance and conservation of snakes of the neglected and endangered Caatinga region, north-eastern Brazil. J. Biogeogr. 41:919-931.

GUEDES, T.B., SAWAYA, R.J., ZIZKA, A., LAFFAN, S., FAUBY, S., PYRON, A., BÉRNILS, R.S.B., JANSEN, M., PASSOS, P., PRUDENTE, A.L., CISNEROS-HEREDIA, D.F., BRAZ, H.B., NOGUEIRA, C.C. \& ANTONELLI, A. 2018. Patterns, biases and prospects in the distribution and diversity of Neotropical snakes. Glob. Ecol. Biogeogr. 27:14-21.

GUYER, C. \& DONNELLY, M.A. 2012. Visual encounter surveys. In Reptiles Biodiversity: standard methods for inventory and monitory (R.W. McDiarmid, M.S. Foster, C. Guyer, J.W. Gibbons \& N. Chernoff, eds.). University of California Press, Berkley and Los Angeles, p.218-220.

ICMBio/MMA (INSTITUTO CHICO MENDES DE CONSERVAÇÃO DA BIODIVERSIDADE/ MINISTÉRIO DO MEIO AMBIENTE). 2018. Livro Vermelho da Fauna Brasileira Ameaçada de Extinção. ICMBio, Brasília, v1, p.1-492.

IUCN (INTERNATIONAL UNION FOR CONSERVATION OF NATURE). 2019. IUCN Red List of threatened species. Version 2019-2. https://www. iucnredlist.org (last access on 05/03/2019).

LEAL, I.R., SILVA, J.M.C., TABARELLI, M. \& LACHER-JR T.E. 2005. Changing the course of biodiversity conservation in the Caatinga of northeastern Brazil. Conserv Biol. 19:701-706.

LEGENDRE, P. \& LEGENDRE, L. 2012. Numerical Ecology. 3d. Elsevier, Amsterdam.

LIEBERMAN, S.S. 1986. Ecology of the leaf litter herpetofauna of a neotropical rain forest: La Selva, Costa Rica. Acta Zool. Mex. 15:1-72. 
LIMA, I.B. \& BARBOSA, M.R.V. 2014. Composição florística da RPPN Fazenda Almas, no Cariri Paraibano, Paraíba, Brasil. Rev. Nordest. Biol. 23:49-67.

LIMA-VERDE, J.S. 1976. Fisioecologia e etologia de algumas serpentes da Chapada do Apodi, Estados do Ceará e Rio Grande do Norte (Brasil). Caatinga 1(1):21-56.

MACEDO, L.M., BERNARDE, P.S. \& ABE, A.S. 2008. Lagartos (Squamata: Lacertilia) em áreas de floresta e de pastagem em Espigão do Oeste, Rondônia, sudoeste da Amazônia, Brasil. Biota Neotrop. 8: 133-139. http:// dx.doi.org/10.1590/S1676-06032008000100016 (last access on 20/02/2008).

MAGALHÃES, F.M., LARANJEIRAS, D.O., COSTA, T.B., JUNCÁ, F.A., MESQUITA, D.O., RÖHR, D.L., SILVA, W.P., VIEIRA, G.H.C. \& GARDA, A.A. 2015. Herpetofauna of protected areas in the Caatinga IV: Chapada Diamantina National Park, Bahia, Brazil. Herpetol. Notes 8:243-261.

MAGURRAN, A.E. 2004. Measuring biological diversity. Blackwell Science, Oxford.

MARQUES, O.A.V. \& SAZIMA, I. 2004. História natural dos répteis da Estação ecológica Juréia-Itatins. In Estação Ecológica Juréia-Itatins. Ambiente físico, flora e fauna (O.A.V. Marques \& W. Duleba, eds.). Holos Editora, Ribeirão Preto, p.257-277.

MARTINS, M. \& NOGUEIRA, C.C. 2012. Collaboration with local people for sampling reptiles. In Reptile Biodiversity Standard Methods for Inventory and Monitoring (W. Roy, M.S. McDiarmid, C.G.J. Foster, G. Whitfield \& N. Chernoff, eds.). University of California Press, Berkeley, p.86-88.

MARTINS, M. \& OLIVEIRA, M.E. 1998. Natural history of snakes in forest of the Manaus region, central Amazonia, Brazil. Herpetol. Nat. Hist. 6:78-150.

MESQUITA, P.C.M.D., PASSOS, D.C., BORGES-NOJOSA, D \& CECHIN, SZ. 2013a. Ecologia e história natural das serpentes de uma área de Caatinga no nordeste brasileiro. Pap. Avulsos Zool. 53(8):99-113.

MESQUITA, P.C.M.D., PASSOS, D.C. \& CECHIN, SZ. 2013b. Efficiency of snake sampling methods in the Brazilian semiarid region. An. Acad. Bras. Cienc. 85(3):1127-1139.

MESQUITA, D.O., COSTA, G.C., GARDA, A.A. \& DELFIM, F.R. 2017. Species Composition, Biogeography, and Conservation of the Caatinga Lizards. In Caatinga: The Largest Tropical Dry Forest Region in South America (J.M.C. Silva, I.R. Leal \& M. Tabarelli, eds.) Springer International Publishing AG, Switzerland, p.151-180.

MIRANDA, A.F.J. \& SANTOS, E.M. 2011. Répteis da Fazenda Saco, Serra Talhada-PE: Indicadores de conservação. In Herpetologia no estado de Pernambuco (G.J.B. Moura, E.M. Santos, M.A.B. Oliveira \& M.C.C. Cabral, eds.). Instituto Brasileiro do Meio Ambiente e Recursos Naturais Renováveis, Centro Nacional de Informação Ambiental, Brasília, p.407-415.

MMA (MINISTÉRIO DO MEIO AMBIENTE). 2002. Avaliação e Ações Prioritárias para a Conservação da Biodiversidade da Caatinga, Ministério do Meio Ambiente, Brasília.

MUNIZ, S.L.S. \& SANTOS, E.M. 2011. Lista preliminar de répteis do vale do Catimbau-Buíque/PE. In Herpetologia no estado de Pernambuco (G.J.B. Moura, E.M. Santos, M.A.B. Oliveira \& M.C.C. Cabral, eds.). Instituto Brasileiro do Meio Ambiente e Recursos Naturais Renováveis, Centro Nacional de Informação Ambiental, Brasília, p.395-405.

NEKOLA, J.C. \& WHITE, P.S. 1999. The distance decay of similarity in biogeography and ecology. ग. Biogeogr. 26:867-878.

NIMER, E. 1972. Climatologia da região Nordeste do Brasil. Introdução à climatologia dinâmica. Rev.Bras.Geo. 34:3-51.

OKSANEN, J., BLANCHET, F.G., FRIENDLY, M., KINDT, R., LEGENDRE, P., MCGLINN, D., MINCHIN, P.R., O'HARA, R.B., SIMPSON, G.L., SOLYMOS, P., STEVENS, M.H.H., SZOECS, E. \& WAGNER, H. 2018. vegan: Community Ecology Package. R package version 2.5-1. Available from: https://CRAN.R-project.org/package=vegan (last access on $10 / 02 / 2019$ )

PARAÍBA. 1985. Atlas geográfico do Estado da Paraíba. Grafset, João Pessoa.

PARDINI, R. \& UMETSU, F. 2006. Non-volant small mammals from the Morro Grande Forest Reserve - distribution of species and diversity in an Atlantic Forest area. Biota Neotrop. 6(2): 1-22 http://www.biotaneotropica.org.br/ v6n2/pt/abstract?article+bn00606022006 (last access on 07/10/2016)
PEDROSA, I.M.M.C., COSTA, T.B., FARIA, R.G., FRANÇA, F.G.R., LARANEIRAS, D.O., OLIVEIRA, T.C.S.P., PALMEIRA, C.N.S., TORQUATO, S., MOTT, T., VIEIRA, G.H.C. \& GARDA, A.A. 2014. Herpetofauna of protected areas in the Caatinga III: The Catimbau National Park, Pernambuco, Brazil. Biota Neotrop. 14(4):1-12. http://dx.doi. org/10.1590/1676-06032014004614 (last access on 10/01/2015).

PENNINGTON, R.T., LAVIN, M. \& OLIVEIRA-FILHO, A.T. 2009. Woody plant diversity, evolution and ecology in the tropics: perspectives from seasonally dry tropical forests. Annu. Rev. Ecol. Evol. Syst. 40:437-457.

PEREIRA, E.N., TELES, M.J.L. \& SANTOS, E.M. 2015. Herpetofauna em remanescente de Caatinga no Sertão de Pernambuco, Brasil. Bol. Mus. Biol. Mello Leitão 37:37-50.

PEREIRA-FILHO, G.A., VIEIRA, W.L.S., ALVES, R.R.N., FRANÇA, F.G.R. 2017. Serpentes da Paraíba: Diversidade e Conservação. João Pessoa.

PONTES ,J.A.L., FIGUEIREDO, J.P., PONTES, R.C. \& ROCHA, C.F.D. 2008. Snakes from the Atlantic Rainforest area of the harvestmen of Southern and southeastern Atlantic Rainforest of Brazil. Braz. J. Biol. 68(3):601-609.

PRADO, D. 2003. As caatingas da América do Sul. In Ecologia e conservação da Caatinga (I.R. Leal, M. Tabarelli \& J.M.C. Silva, eds.). Editora Universitária da UFPE, Recife, p.3-73.

QUEIROZ, L.P., CARDOSO, D., FERNANDES, M.F. \& MORO, M.F. 2017. Diversity and Evolution of Flowering Plants of the Caatinga Domain. In Caatinga: The Largest Tropical Dry Forest Region in South America (J.M.C. Silva, I.R. Leal \& M. Tabarelli, eds.). Springer International Publishing AG, Switzerland, p.23-63.

QUINTELA, F.M., LOEBEMANN, D. \& GIANUCA, N.M. 2006. Répteis continentais do município de Rio Grande, Rio Grande do Sul, Brasil. Biociências 14(2):180-186

R CORE TEAM. 2018. R: A language and environment for statistical computing. R Foundation for Statistical Computing, Vienna.

RIBEIRO, S.C., ROBERTO, I.J., SALES, D.L., ÁVILA, R.W. \& ALMEIDA, W.O. 2012. Amphibians and reptiles from the Araripe bioregion, northeastern Brazil. Salamandra 48(3):133-146.

RODRIGUES, M.T. 1996. Lizards, snakes, and amphisbaenia from the quaternary sand dunes of the middle Rio São Francisco, Bahia, Brazil. J. Herpetol. 30:513-523.

RODRIGUES, M.T. 2003. Herpetofauna da Caatinga. In Ecologia e conservação da Caatinga (I. Leal, M. Tabarelli \& J.M.C. Silva, eds.). Universidade Federal de Pernambuco, Recife, p.181-236.

RODRIGUES, M.T. \& JUNCÁ, F.C. 2002. Herpetofauna of the quaternary sand dunes of the middle Rio São Francisco: Bahia: Brazil. VII. Typhlops amoipira sp. nov., a possible relative of Typhlops yonenagae (Serpentes, Typhlopidae). Pap. Avulsos Zool. 42(13):325-333.

RODRIGUES, F.S. \& PRUDENTE, A.L.C. 2011. The snake assemblage (Squamata: Serpentes) of a Cerrado-Caatinga transition area in Castelo do Piauí, state of Piauí, Brazil. Zoologia 28 (4):440-448.

RODRIGUES, J.B., GAMA, S.C.A., PEREIRA-FILHO, G.A. \& FRANÇA, F.G.R. 2015. Composition and ecological aspects of a snake assemblage on the savanna enclave of the Atlantic Forest of the Guaribas Biological Reserve in Northeastern Brazil. South American J. Herpetol. 10(3):1-8.

SAMPAIO, I.L.R., SANTOS, C.P., FRANÇA, R.C., PEDROSA, I.M.M.C., SOLÉ, M. \& FRANÇA, F.G.R. 2018. Ecological diversity of a snake assemblage from the Atlantic Forest at the south coast of Paraíba, northeast Brazil. ZooKeys 787:107-125.

SANTANA, G.G., VIEIRA, W.L.S., PEREIRA-FILHO, G.A., DELFIM, F.R., LIMA, Y.C.C. \& VIEIRA, K.S. 2008. Herpetofauna de um fragmento de Floresta Atlântica no Estado da Paraíba, Região Nordeste do Brasil. Biotemas 21(1):75-84.

SANTOS, T.G., KOPP, K.A., SPIES, M.R., TREVISAN, R. \& CECHIN, S.Z. 2005. Répteis do campus da Universidade Federal de Santa Maria, RS, Brasil. Biota Neotrop. 5(1):171-1178 http://dx.doi.org/10.1590/S167606032005000100016 (last access on 05/04/2005).

SAWAYA, R.J. 2003. História natural e ecologia das serpentes do cerrado da região de Itirapina, SP. Tese de Doutorado, Universidade Estadual de Campinas, Campinas. 
SAWAYA, R.J., MARQUES, O.A.V. \& MARTINS, M. 2008. Composição e história natural das serpentes de Cerrado de Itirapina, São Paulo, Sudeste do Brasil. Biota Neotrop. 8(2):127-148. https://doi.org/10.1590/S167606032008000200015 (last access on 05/08/2008).

SAZIMA, I. \& HADDAD, C.F.B. 1992. Répteis da Serra do Japi: notas sobre história natural. In História natural da Serra do Japi: ecologia e preservação de uma área de floresta no sudeste do Brasil (L.P.C. Morellato, ed.). São Paulo, p.212-236.

SILVA, M.B., CARVALHO, L.S. \& RODRIGUES, V. 2015. Reptiles in an ecotonal area in northern State of Piauí, Brazil. Bol. Mus. Biol. Mello Leitão 37(4):437-455.

SILVA, M.B., ROCHA, W.A. \& NOGUEIRA-PARANHOS, J.D. 2016. Checklist of reptiles of the Amazonia-Caatinga-Cerrado ecotonal zone in eastern Maranhão, Brazil. Herpetol. Notes 9:7-14.

SILVA, J.M.C., BARBOSA, L.C.F., LEAL, I.R. \& TABARELLI, M. 2017. The Caatinga: Understanding the Challenges. In Caatinga: The Largest Tropical Dry Forest Region in South America (J.M.C. Silva, I.R. Leal \& M. Tabarelli, eds.). Springer International Publishing AG, Switzerland, p.3-19.

SOUZA, B.I., SLAINS, A.M.B.P. \& SANTOS, J.B. 2004. Contribuição ao estudo de desertificação na Bacia do Taperoá. Agriambi 8 (2/3):292-298.

STRÜSSMANN, C. \& SAZIMA, I. 1993. The snakes assemblage of the pantanal at Poconé, western Brazil: Faunal composition and ecological summary. Stud. Neotrop. Fauna Environ. 28:157-168.

TABARELLI, M. \& SILVA, J.M.C. 2003. Áreas e ações prioritárias para conservação da biodiversidade da Caatinga. In Ecologia e Conservação da Caatinga (I.R. Leal, M. Tabarelli \& J.M.C Silva, eds.). Editora Universitária da Universidade Federal de Pernambuco. Recife, p.777-796.

UGLAND, K.I., GRAY, J.S. \& ELLINGSEN, K.E. 2003. The species accumulation curve and estimation of species richness. J. Animal Ecol 72:888-897.

VANZOLINI, P.E. 1974. Ecological and geographical distribution of lizards in Pernambuco, northeastern Brazil (Sauria). Pap. Avulsos Zool. 28:61-90.
VANZOLINI, P.E. 1988. Distributional patterns of south american lizards. In Proceedings of a workshop on Neotropical distribution patterns (P.E. Vanzolini \& W.R. Heyer, eds.). An. Acad. Bras. Ciênc., p.317-342.

VANZOLINI, P.E. \& WILLIAMS, E.E. 1981. A quase-historical approach to the natural history of the differentiation of reptiles in tropical geographic isolates. Pap. Avulsos Zool. 34(19):189-204.

VANZOLINI, P.E., RAMOS-COSTA, A.M.M. \& VITT, L.J. 1980. Répteis das Caatingas. Academia Brasileira de Ciências, Rio de Janeiro.

VELLOSO, A., SAMPAIO, E.V.S.B. \& PAREYN, F.G.C. 2002. Ecorregiões: propostas para o bioma Caatinga. Instituto de Conservação ambiental. The Nature coservancy do Brasil, Associação Plantas do Nordeste, Recife.

VIANA, B.F., SILVA, F.O. \& KLEINERT, A.M.P. 2001. Diversidade e sazonalidade de abelhas solitárias (Hymenoptera: Apoidae) em dunas litorâneas no nordeste do Brasil. Neotrop. Entomol. 30(2):245-251.

VITT, L.J. \& VANGILDER, L.D. 1983. Ecology of a snake community in northeastern Brazil. Amphibia-Reptilia 4:273-296.

WILLIG, M.R. \& BLOCH, C.P. 2006. Latitudinal gradients of species richness: a test of the geographic area hypothesis at two ecological scales. Oikos 112:163-73.

XAVIER, A.L., GUEDES, T.B. \& NAPOLI, M.F. 2015. Biogeography of anurans from the poorly known and threatened coastal sandplains of eastern Brazil. PloS One 10(6): e0128268. http://journals.plos.org/plosone/ article?id=10.1371/journal.pone.0128268 (last access on 26/12/2019).

ZANELLA, N. \& CECHIN, S.Z. 2006. Taxocenose de serpentes no planalto médio do Rio Grande do Sul. Rev. Bras. Zool. 23(1):211-217.

ZIMMERMAN, B.L. \& RODRIGUES, M.T. 1990. Frogs, snakes, and lizards of the INPA - WWF Reserve near Manaus, Brazil. In Four neotropical rainforests (A.H. Gentry, ed.). Yale University Press, New Haven, p.427-454.

Received: 02/08/2019

Revised: $30 / 07 / 2020$

Accepted: $31 / 07 / 2020$

Published online: 14/08/2020 